\title{
1999 Volcanic Activity in Alaska and Kamchatka: Summary of Events and Response of the Alaska Volcano Observatory
}

by Robert G. McGimsey, Christina A. Neal, and Olga Girina

Open-File Report 2004-1033

U.S. Department of the Interior U.S. Geological Survey

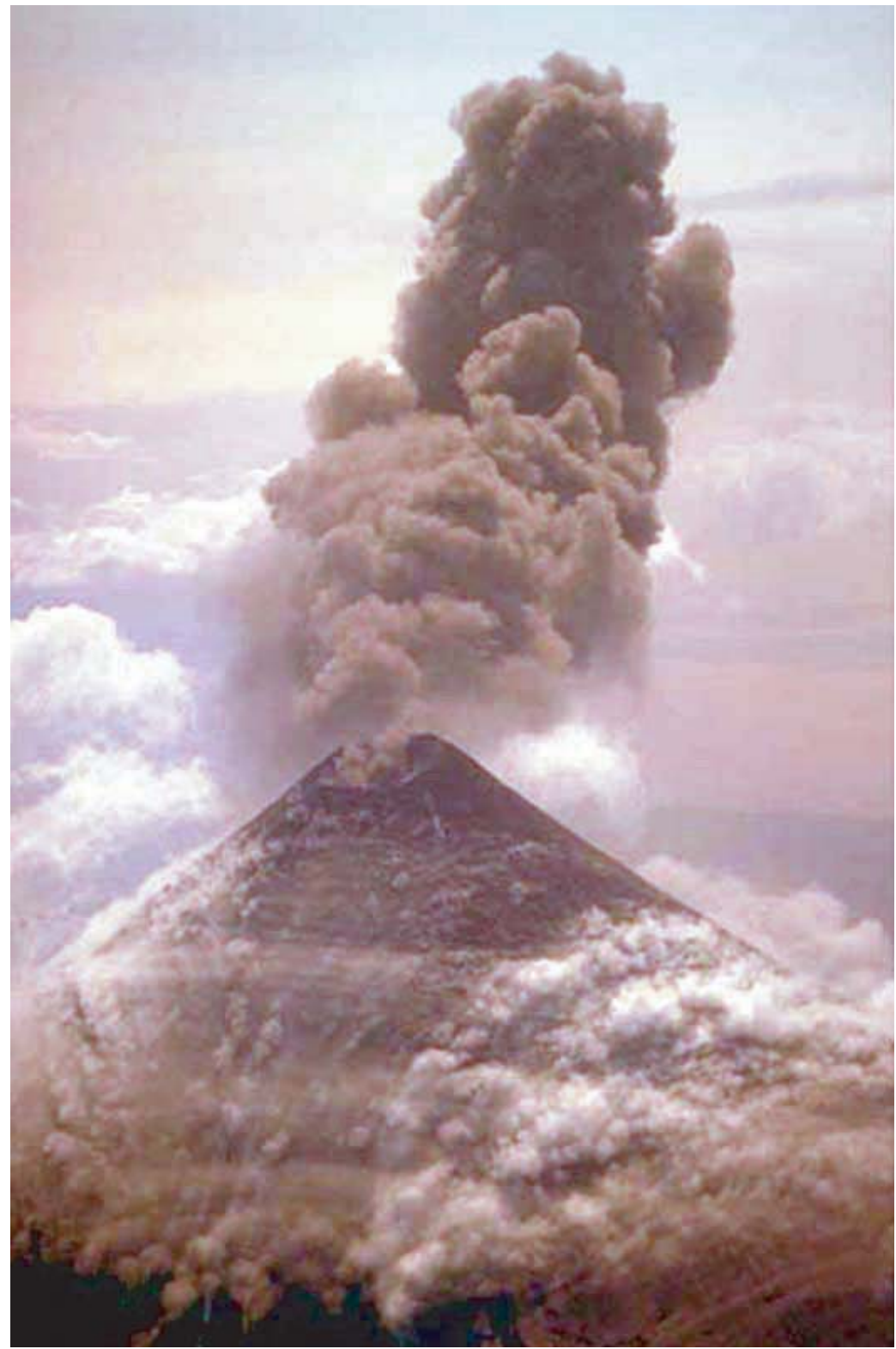




\section{Volcanic Activity in Alaska and Kamchatka: Summary of Events and Response of the Alaska Volcano Observatory}

By Robert G. McGimsey ${ }^{1}$, Christina A. Neal ${ }^{1}$, and Olga Girina ${ }^{2}$

${ }^{1}$ Alaska Volcano Observatory, 4200 University Dr., Anchorage, AK 99508-4664

2Kamchatka Volcanic Eruptions Response Team, Institute of Volcanic Geology and Geochemistry, Piip Blvd, 9 Petropavlovsk-Kamchatsky, 683006, Russia

AVO is a cooperative program of the U.S. Geological Survey, University of Alaska Fairbanks Geophysical Institute, and the Alaska Division of Geological and Geophysical Surveys. AVO is funded by the U.S. Geological Survey Volcano Hazards Program and the State of Alaska

Any use of trade, firm, or product names is for descriptive purposes only and does not imply endorsement by the U.S. Government

Open-File Report 2004-1033 


\section{TABLE OF CONTENTS}

\section{CONTENTS}

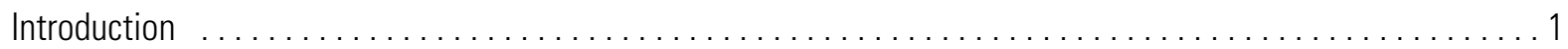

Reports of volcanic activity, northeast to southwest along Aleutian arc ................... 4

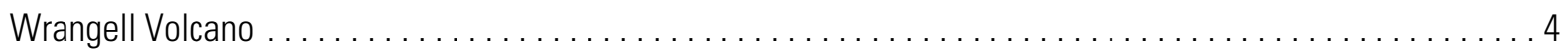

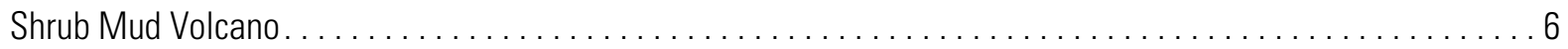

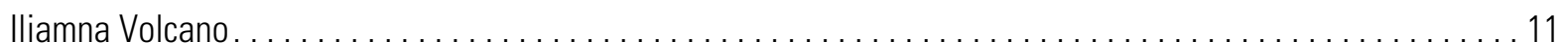

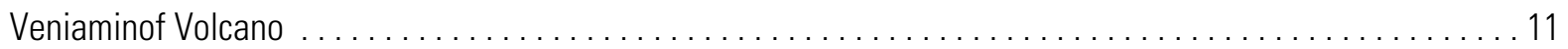

Pavlof Volcano . . . . . . . . . . . . . . . . . . . . . . . . . . . . . . . . . . . . . . . 12

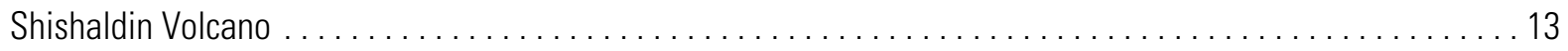

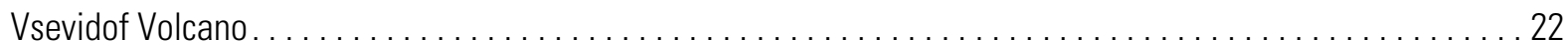

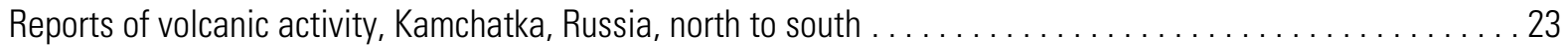

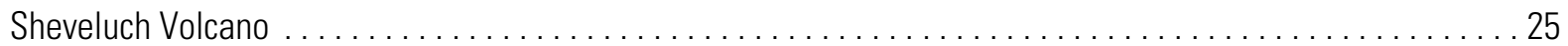

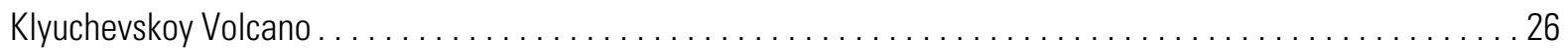

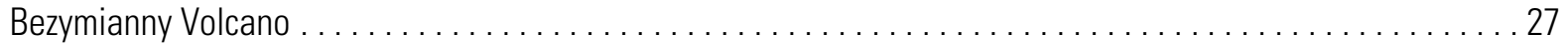

Karymsky Volcano . . . . . . . . . . . . . . . . . . . . . . . . . . . . . . . . . . . . . 29

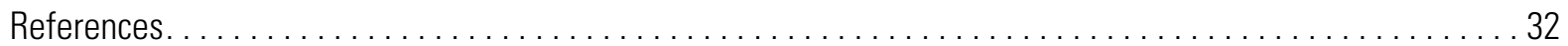

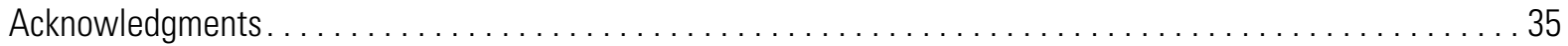

\section{FIGURES}

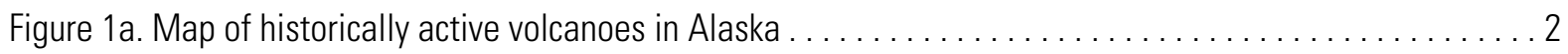

Figure 1b. Map showing volcanoes monitored with a seismic network as of the end of $1999 \ldots \ldots \ldots \ldots 3$

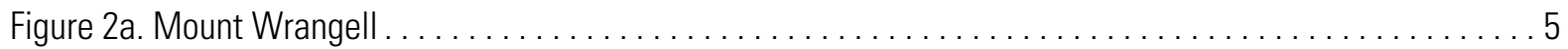

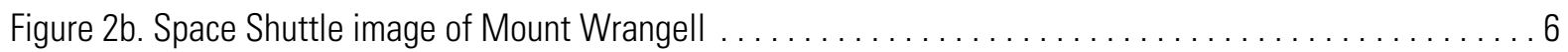

Figure 3. Location map for Shrub and Klawasi group mud volcanoes $\ldots \ldots \ldots \ldots \ldots \ldots \ldots \ldots \ldots \ldots \ldots$

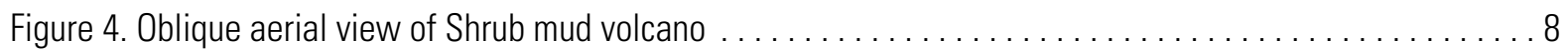

Figure 5. Map of Shrub mud volcano showing vent locations and temperatures $\ldots \ldots \ldots \ldots \ldots \ldots \ldots$

Figure 6. Mike Sorey (USGS) and Cindy Werner (Penn State University) measure $\mathrm{CO}_{2} \ldots \ldots \ldots \ldots \ldots \ldots$

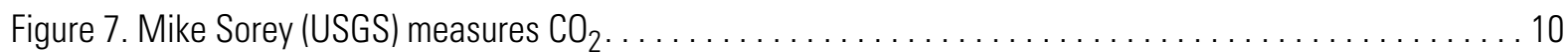

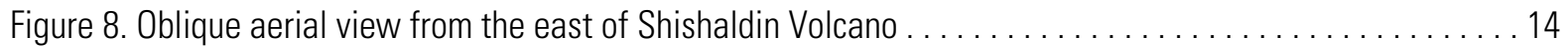

Figure 9 a. In the visual image, steam clouds obscure the summit of Shishaldin $\ldots \ldots \ldots \ldots \ldots \ldots \ldots$

Figure 9b. FLIR image shows strombolian lava fountaining in summit crater $\ldots \ldots \ldots \ldots \ldots \ldots \ldots \ldots$

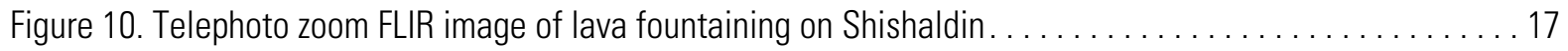

Figure 11. A time series of GOES satellite images of April 19, 1999 eruption plume at Shishaldin ......... 18

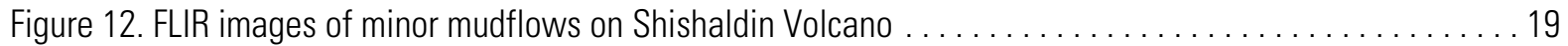

Figure 13. Map of Shishaldin Volcano showing topography and 1999 deposits . . . . . . . . . . . . . 21

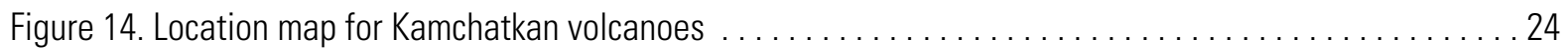

Figure 15. Track of ash plume from February 24, 1999 eruption of Bezimianny $\ldots \ldots \ldots \ldots \ldots \ldots \ldots \ldots$

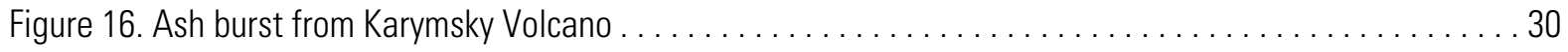




\section{TABLE OF CONTENTS}

\section{TABLES}

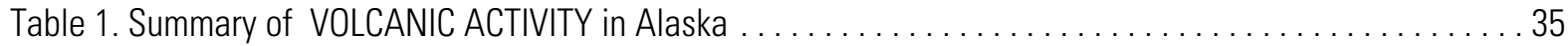

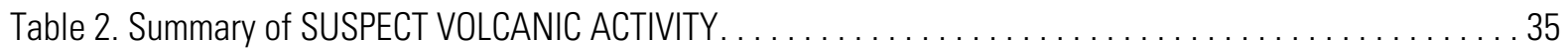

Table 3. Record of changes in the Level of Concern Color Code of Shishaldin Volcano . . . . . . . . . . . . 36

Table 4. Summary of VOLCANIC ACTIVITY on Kamchatka Peninsula, Russia . . . . . . . . . . . . . . . . . . . . . 37

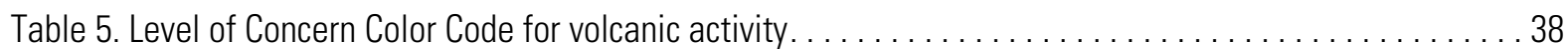

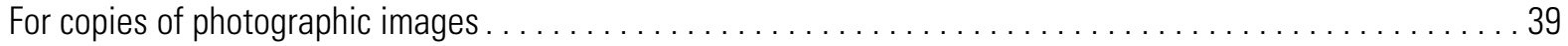

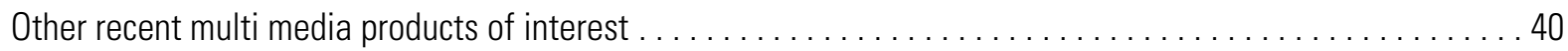

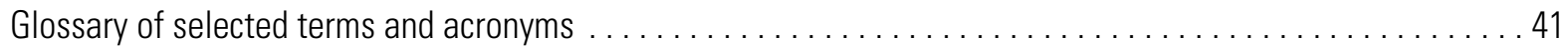

COVER PHOTO: Small explosive ash plume that occurred 10 hours after the end of the April 23, 1999 eruptive phase of Shishaldin Volcano. Photo by R.G. McGimsey. 


\section{INTRODUCTION}

The Alaska Volcano Observatory (AVO) monitors 41 historically active volcanoes along the Aleutian Arc (fig. 1a). Twenty are seismically monitored and for the rest, the AVO monitoring program relies mainly on daily analysis of satellite images, pilot reports, and observations of local residents and ship's crews. In 1999, AVO responded to eruptive activity or suspect volcanic activity at 7 volcanic centers (tables $1 \&$ 2; fig. 1a): Wrangell, Shrub mud volcano, Iliamna, Veniaminof, Pavlof, Shishaldin, and Vsevidof volcanoes. Of these, in 1999, AVO had real-time, continuously recording seismic networks at Iliamna, and Shishaldin. The phrase "suspect volcanic activity" (SVA), used to characterize several responses, is an eruption report or report of unusual activity that is subsequently determined to be normal or enhanced fumarolic activity, weather-related phenomena, or a non-volcanic event.

In addition to responding to eruptive activity at Alaska volcanoes, AVO also disseminated information for the Kamchatkan Volcanic Eruption Response Team (KVERT) about the 1999 activity of four Russian volcanoes: Sheveluch, Klyuchevskoy, Bezimianny, and Karymsky volcanoes (fig. 14 ; table 4).

This report summarizes volcanic activity and SVA in Alaska during 1999 and the AVO response, as well as information on the reported activity at the Russian volcanoes. Only those reports or inquiries that resulted in a "significant" investment of staff time and energy (here defined as several hours or more for reaction, tracking, and follow-up) are included. AVO typically receives dozens of reports throughout the year of steaming, unusual cloud sightings, or eruption rumors. Most of these are resolved quickly and are not tabulated here as part of the 1999 response record.

Descriptions of volcanic activity and AVO responses are presented in geographical order from northeast to southwest along the Aleutian volcanic arc. All elevations reported are above sea level (ASL) unless noted, and time is reported as Alaska Standard Time (AST), Alaska Daylight Time (ADT), or Kamchatkan Standard Time (KST), Kamchatkan Daylight Time (KDT) (see glossary). The time of satellite image acquisition is usually given in Universal Coordinated Time (UTC, typically reported in the form 0000Z). A summary of volcanic activity is presented in Table 1. SVA that required a significant response are summarized in Table 2. Table 4 summarizes volcanic activity and responses in Kamchatka and Table 5 explains the Level of Concern Color Code for volcanic activity at seismically monitored volcanoes. Information on 1999 responses is compiled from AVO weekly updates and information releases, the AVO 1999 "Chron book" - a chronological collection of daily or weekly staff notes for a particular year-the AVO daily satellite logs, and the Smithsonian Institution Global Volcanism Network Bulletin (GVN), which often uses $\mathrm{AVO}$ as the source for reports on Alaska volcanoes.

AVO response to reported remote volcanic activity varies depending on the source and content of the observation. After receiving a report and possibly conducting follow-up investigation of the factual information, AVO usually contacts the National Weather Service (NWS) and Federal Aviation Administration (FAA) for corroboration and/or formal notification. For a verified, significant eruption, an established call-down procedure to formally notify other government agencies, air carriers, facilities at risk, and the media is initiated. If an eruption is not confirmed, a notation 
is made in the AVO Chron book and no further action is taken. A special information release may be distributed if eruptive activity is confirmed, and the events are further summarized in the AVO weekly update distributed each Friday via electronic mail and facsimile.

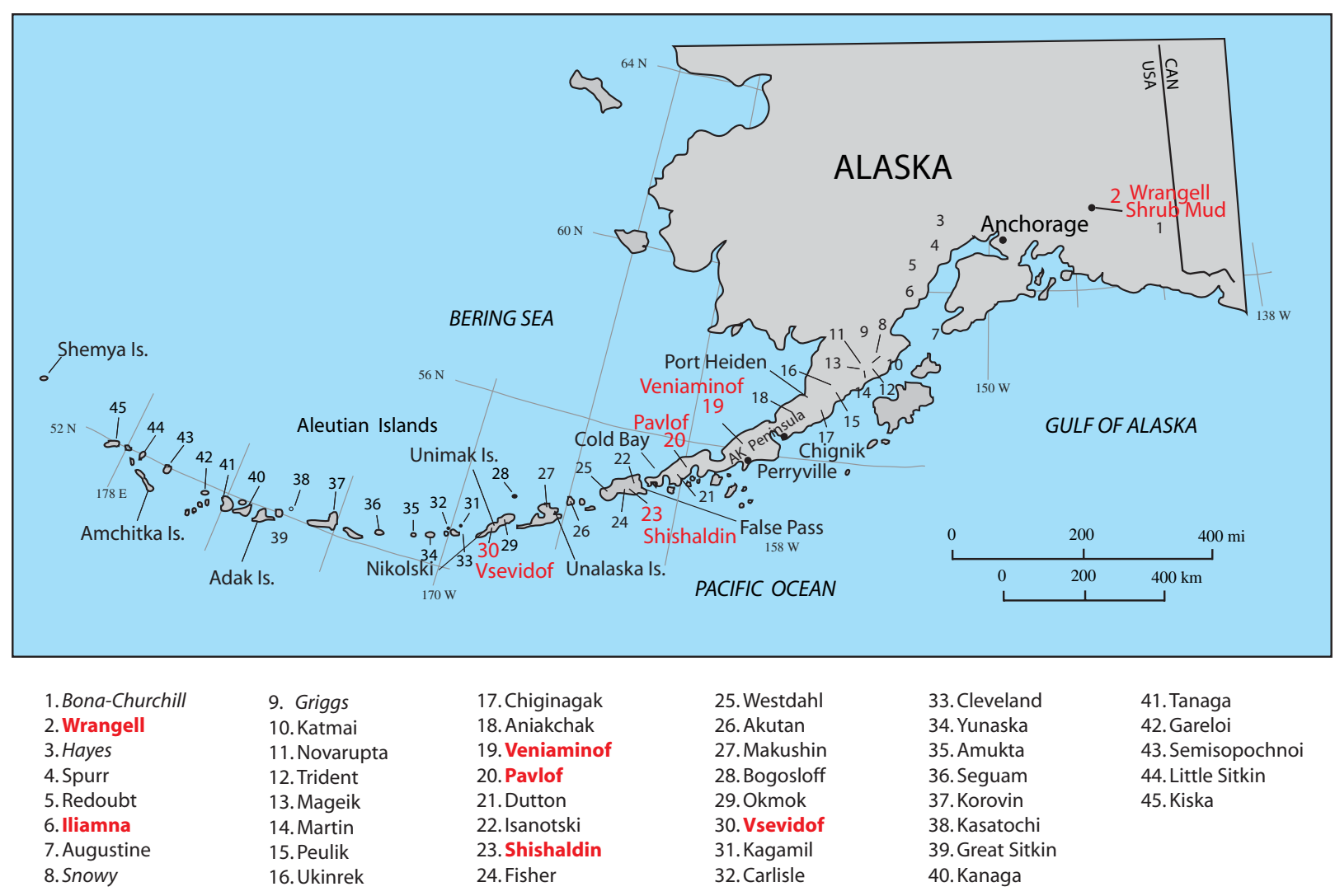

Figure 1a. Location of historically active volcanoes in Alaska and place names used in this summary. Volcanoes mentioned in this report are in bold red. Volcanoes with no documented historical unrest but currently considered hazardous based on late-Holocene eruptive activity are italicized. 


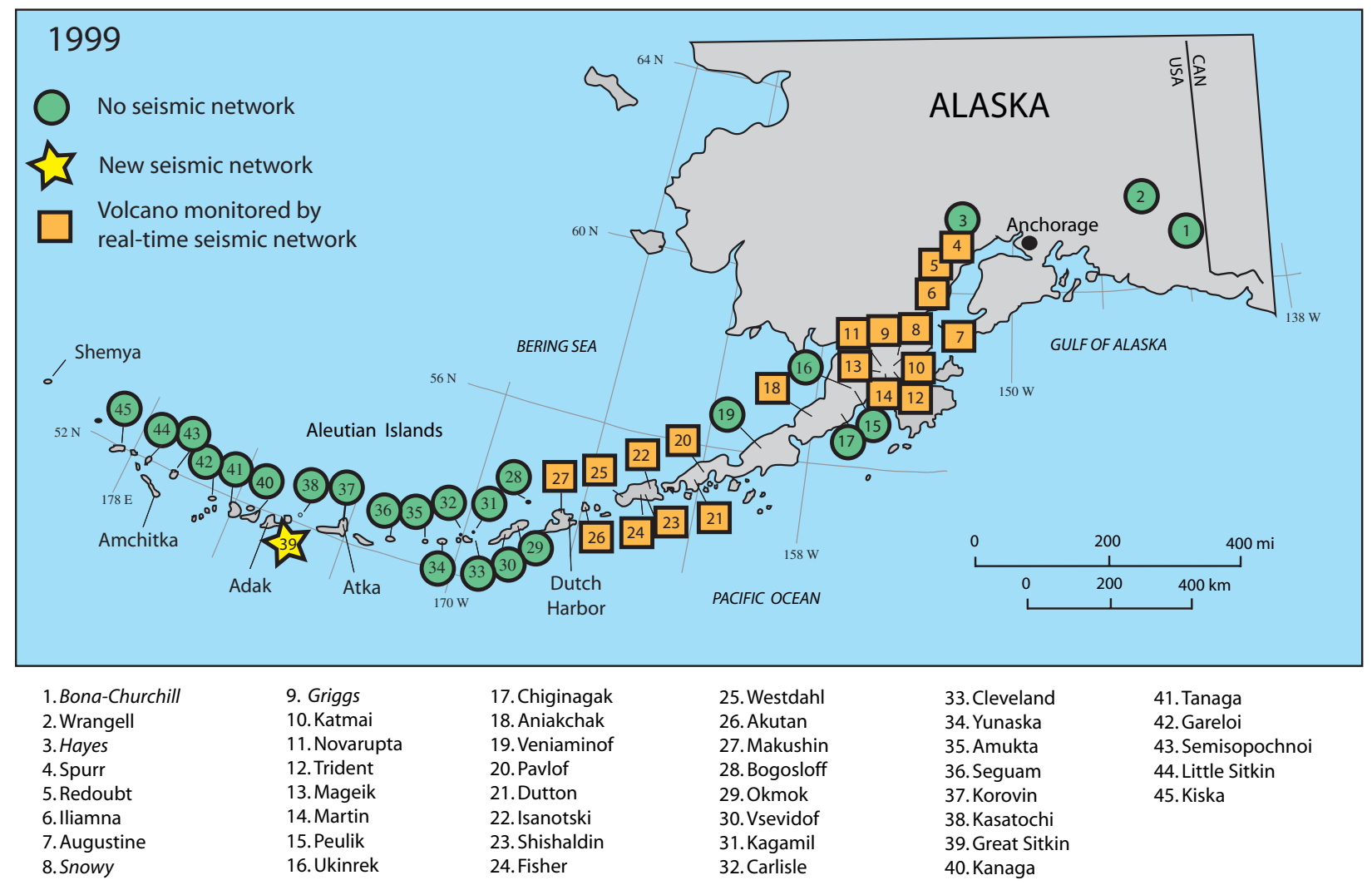

Figure 1b. Map showing those volcanoes monitored with a seismic network as of the end of 1999. Volcanoes with no documented historical unrest but still considered hazardous based on late-Holocene eruptive activity are italicized. 


\title{
VOLCANIC ACTIVITY IN ALASKA
}

\section{NORTHEAST TO SOUTHWEST ALONG ALEUTIAN ARC}

Steam observations:

AVO annually receives reports of steaming at Alaska volcanoes. Some reports are from volcanoes with long-lived fumarolic zones (e.g. Wrangell, Redoubt, Iliamna, Martin, Mageik, Chiginagak, Pavlof, Shishaldin, and Gareloi to mention a few). Plume sightings are usually most frequent during calm periods of clear, cool weather conditions. Some reports originate from pilots flying over remote volcanoes (e.g. Aleutian Islands) and others from residents in remote villages. AVO personnel collectively spend a significant amount of time receiving, documenting, responding to, and following-up these reports.

\author{
WRANGELL VOLCANO \\ CAVW \#1105-02 \\ $62^{\circ} 00^{\prime} \mathrm{N} 144^{\circ} 00^{\prime} \mathrm{W}$ \\ $14,163 \mathrm{ft}(4,317 \mathrm{~m})$ \\ SUSPECT VOLCANIC ACTIVITY \\ Unusual steaming and ash emission, and probable glacier surge
}

On the morning of May 14, 1999, a NWS observer in Gulkana reported anomalous steam-with minor ash-emission at Wrangell Volcano. At approximately 9:30 AM ADT, a sudden, rapidly billowing, grayish and white cloud rose to about 3,000 feet above the north summit crater. The weather was clear with calm winds out of the south. The observer stated that at this time of year, on clear days, a small, wispy, steam plume is usually visible above Wrangell in the early morning, and dissipates by early afternoon. On this day, the plume developed quickly, was abnormally voluminous, and had a grayish color.

We learned from interviewing a local pilot (Lin Ellis), flying a routine mail run, that he had also observed the activity at Wrangell while passing by the south-southwest flank at 10,000 feet ASL. Additionally, he noticed that more "dirt" surrounded the north crater than usual, and, that on the upper part of the Chestnina Glacier-high on the southwest flank-blocks of ice were chaotically jumbled (higher relief between blocks) and that the glacier surface was much more crevassed than he had ever previously seen. He also observed that of two known fumaroles located at about the 11,000 -foot level $(3,350 \mathrm{~m})$ on the south flank that typically issue steam through ice holes, one was now surrounded by a sizeable patch of bare rock. This, too, was a new development since his last recent flight over the area. Ellis further reported that he had seen no sign of flowage or melting events (high on flank), but that he had not flown over the lower reaches of the glacier.

As of 5 PM, the NWS observer in Gulkana could still see a small steam plume and with binoculars could see that the snow around the summit area appeared to be light gray and that this was a definite color contrast and not an effect from shadows. AVO conducted follow-up phone calls to confirm that activity had returned to "normal". 
Mount Wrangell is an unusually large, glacier-covered, andesitic shield volcano in the WrangellSt. Elias National Park and Wilderness (Wood and Kienle, 1990). A 4 x 6 km, (2.5 x 3.7 mi) icefilled summit caldera (non-explosive) contains three post-caldera craters: North Crater, East Crater, and Mt. Wrangell Crater. Historical activity is poorly known and appears limited to fumaroles and minor phreatic eruptions from the summit craters-most recently $(1996,1997)$ from North Crater (see, Neal and McGimsey, 1997; McGimsey and Wallace, 1999). Periodic heat flux to the summit area that caused local melting and increased fumarolic and phreatic activity has followed several major regional earthquakes (e.g. 1899, 1964). No seismic instruments were installed on Mt. Wrangell in 1999.

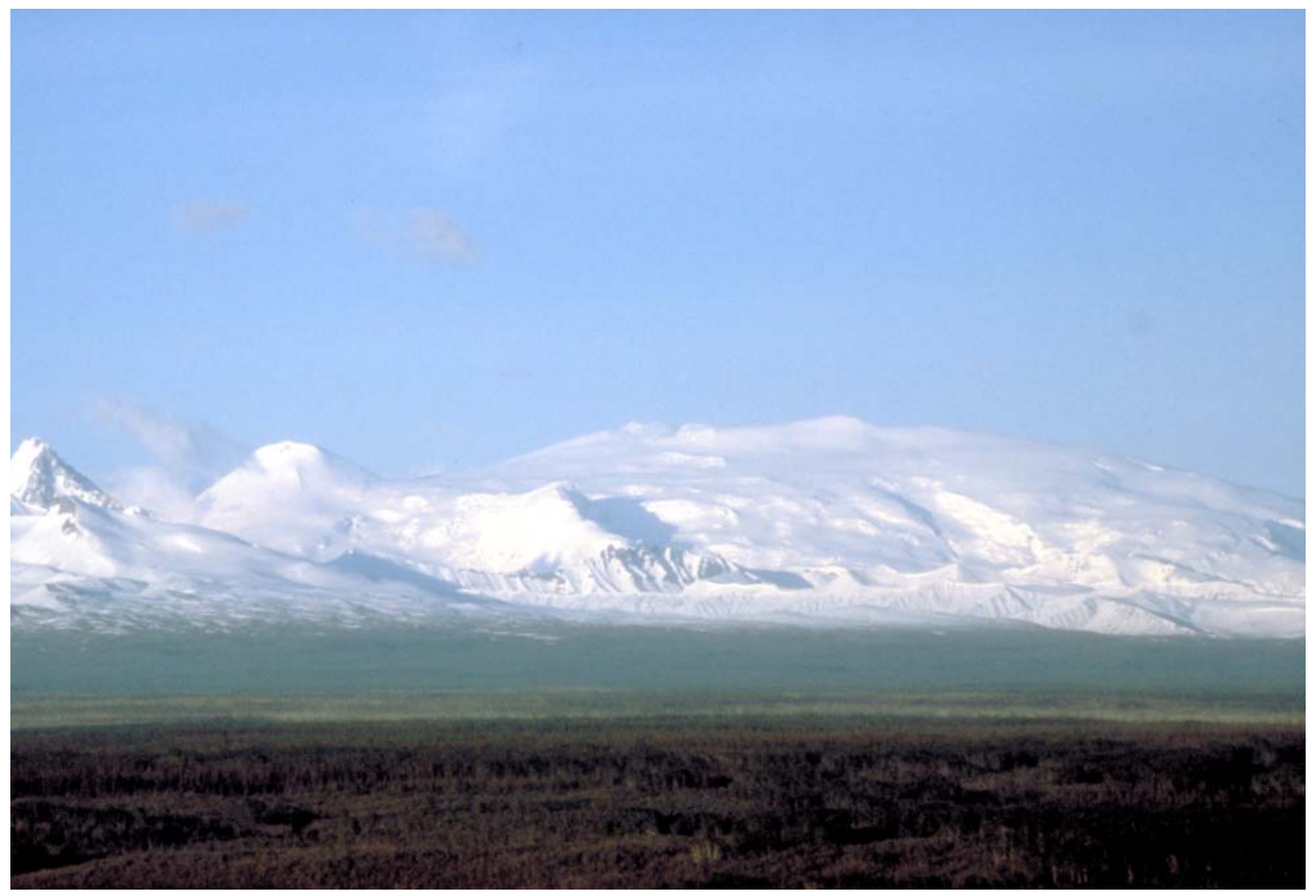

Figure 2a. Mount Wrangell, a 4,317-m-high (14,163 ft) andesite shield volcano on the right skyline. At left is Mount Zanetti, a 3,965-m-high (13,009 ft) cone. View is to the northeast. Photo by B. Cella, U.S. National Park Service, 1987. 


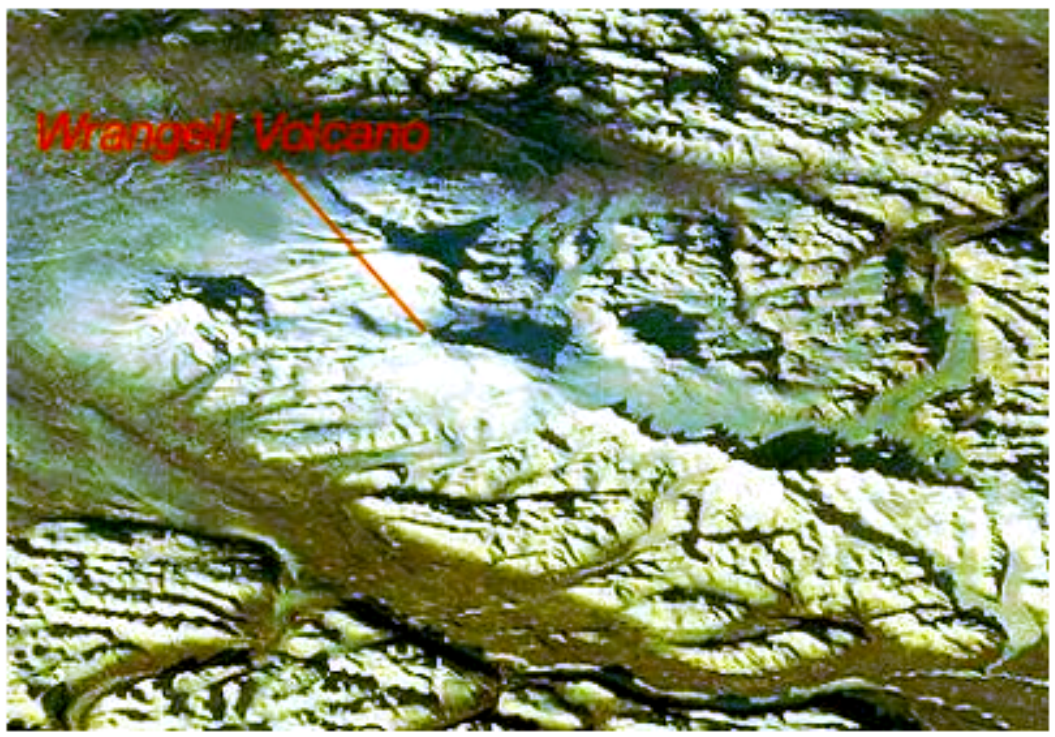

Figure 2b. Space Shuttle Image 61A-476-002 - Mt. Wrangell is located in south central Alaska. This volcano was named after Baron Ferdinand Petrovich von Wrangell, the Governor of Alaska from 1830-1836.

\section{SHRUB MUD VOLCANO}

$62^{\circ} 08^{\prime} \mathrm{N} 145^{\circ} 02^{\prime} \mathrm{W}$

$2,943 \mathrm{ft}(897 \mathrm{~m})$

ERUPTION continues

Emission of warm saline mud and $\mathrm{CO}_{2}$

Shrub, one of three large mud volcanoes of the Klawasi group of mud volcanoes, is located approximately $27 \mathrm{~km}(17 \mathrm{mi})$ east of Glennallen near the west slope of Pleistocene volcano, Mount Drum, in the Copper River Basin of southcentral Alaska (figs. 3 and 4) (Richter and others, 1995). The area is within Wrangell-St. Elias National Park and Preserve. Shrub rises $\sim 100 \mathrm{~m}$ ( $\sim 340 \mathrm{ft}$. ) above surrounding terrain and is composed in part of deposits derived from underlying glaciolacustrine sediments of the Basin (Richter and others, 1998a). Low-level mud and minor gas emission has historically been almost constant at the other two mud volcanoes; however, Shrub has been virtually inactive for decades with only some minor discharge observed in the mid1950's (Nichols and Yehle, 1961). During the spring of 1997, Shrub began to vigorously erupt $\mathrm{CO}_{2}$-rich gas and warm saline mud with minor emissions beginning perhaps in 1996 (Richter and others, 1998a). The activity continued throughout 1997 (McGimsey and Wallace, 1999), 1998, and through 1999. 


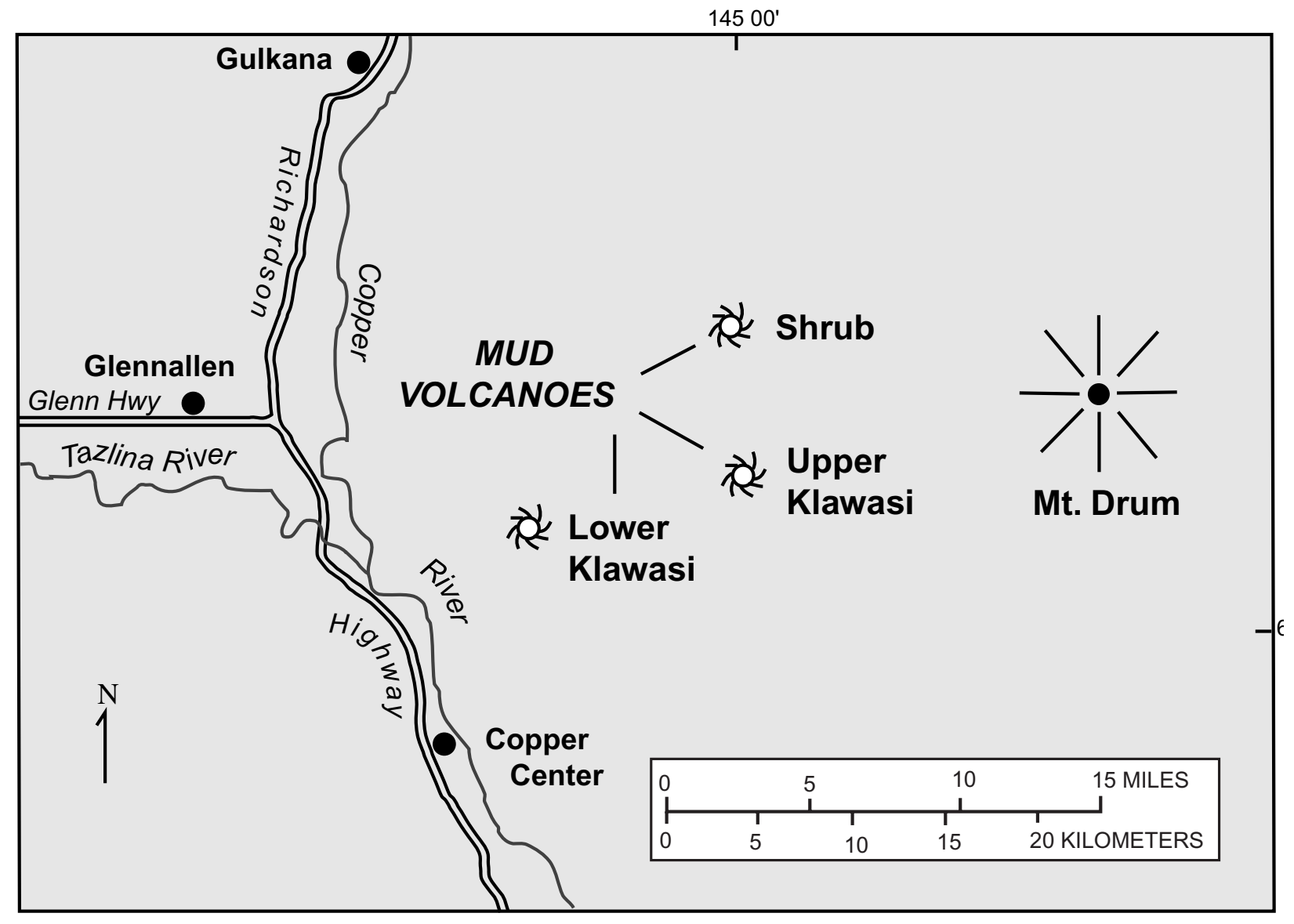

Figure 3. Location map for Shrub and Klawasi group mud volcanoes (Richter and others, 1998a).

Shrub mud volcano was visited on June 23 and 24, 1999 as part of an informal joint National Park Service (NPS) and U.S. Geological Survey project to monitor the activity that began in the spring of 1997. All of the known vent areas were visited and remapped. Temperature of the mud was measured at numerous vents, (fig. 5), $\mathrm{CO}_{2}$ discharge was determined for several vents (figs. 6 and 8 ), diffuse $\mathrm{CO}_{2}$ flux in the soil was measured in a grid section, and several new vents were discovered and documented (Sorey and others, 2000). As in 1998, all of the active vents were quietly discharging mud and gas from bubbling mud pools or ponds. Temperatures as high as $54^{\circ} \mathrm{C}(5-$ $7^{\circ} \mathrm{C}$ higher than those recorded in June 1998) were measured (Sorey and others, 2000). Surprisingly, several new vents were discovered that were discharging mildly turbid water at ambient 


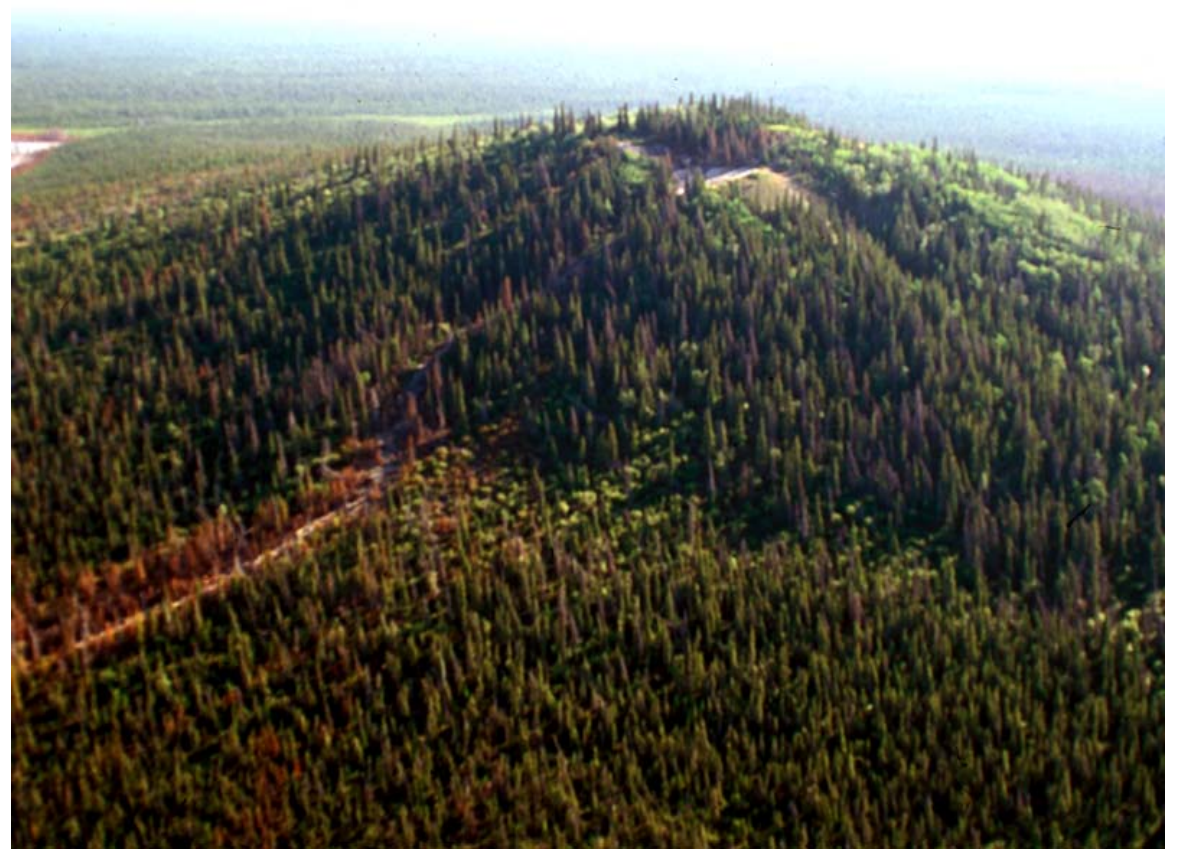

Figure 4. Oblique aerial view of Shrub mud volcano. View is from the southwest looking to the northeast. Photo by R.G. McGimsey, $7 / 31 / 98$.

temperatures $\left(9.5-14^{\circ} \mathrm{C}\right)$. The new vents were located only a few meters away from those discharging highly turbid, warm water $\left(48^{\circ} \mathrm{C}\right)$. All vents, regardless of mud content and temperature, were discharging gas comprised $98 \% \mathrm{CO}_{2}$. An estimated 10 metric tonnes of $\mathrm{CO}_{2}$ per day is discharging from spring vents on Shrub, and along with measured concentrations of bicarbonate, a total $\mathrm{CO}_{2}$ upflow from depth of 20-40 metric tonnes per day was estimated by Sorey and others (2000). Measurements of diffuse degassing rates from soil in an area of recent vegetation kill indicated high $\mathrm{CO}_{2}$ concentrations in the root zone $\left(26 \% \mathrm{CO}_{2}\right.$ at $10 \mathrm{~cm}$ depth). Several small, dead animals near the vents and newly killed vegetation were indicative of the continuing $\mathrm{CO}_{2}$ hazard at Shrub.

More than 500,000 $\mathrm{m}^{3}$ of mud have been erupted since activity began in the spring of 1997 (Richter and others, 1998a). New aerial photography flown on August 14, 1998 was used to more precisely map the extent of mud deposits and main vent locations (fig. 5; after Richter and others, 1998b). The extent of mud deposits in 1999 was largely the same as in 1998. 


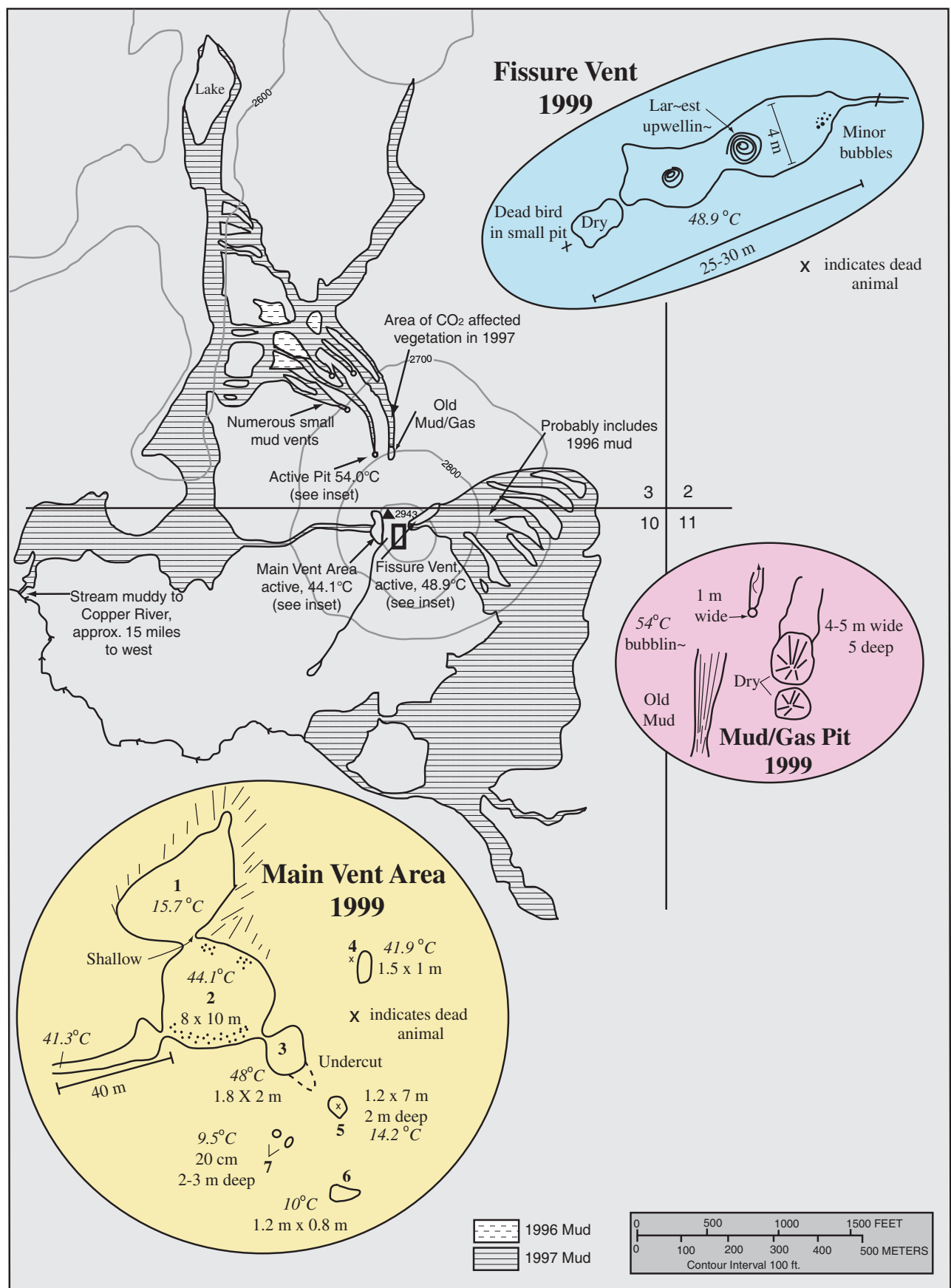

Base from U.S. Geological Survey Gulkana A-3 quadrangle, Alaska; mud deposits from U.S. Bureau of Land Management aerial photography taken August 14, 1998; Graphics by K. Wallace

Figure 5. Map of Shrub mud volcano showing vent locations and temperatures on June 23, 1999, extent of mud deposits in August, 1998 (Richter and others, 1998b), and inset sketches of vent areas (not to scale). Approximate location of the area of diffuse gas flow measurements is denoted by an open rectangle between Main Vent and Fissure Vent area. 


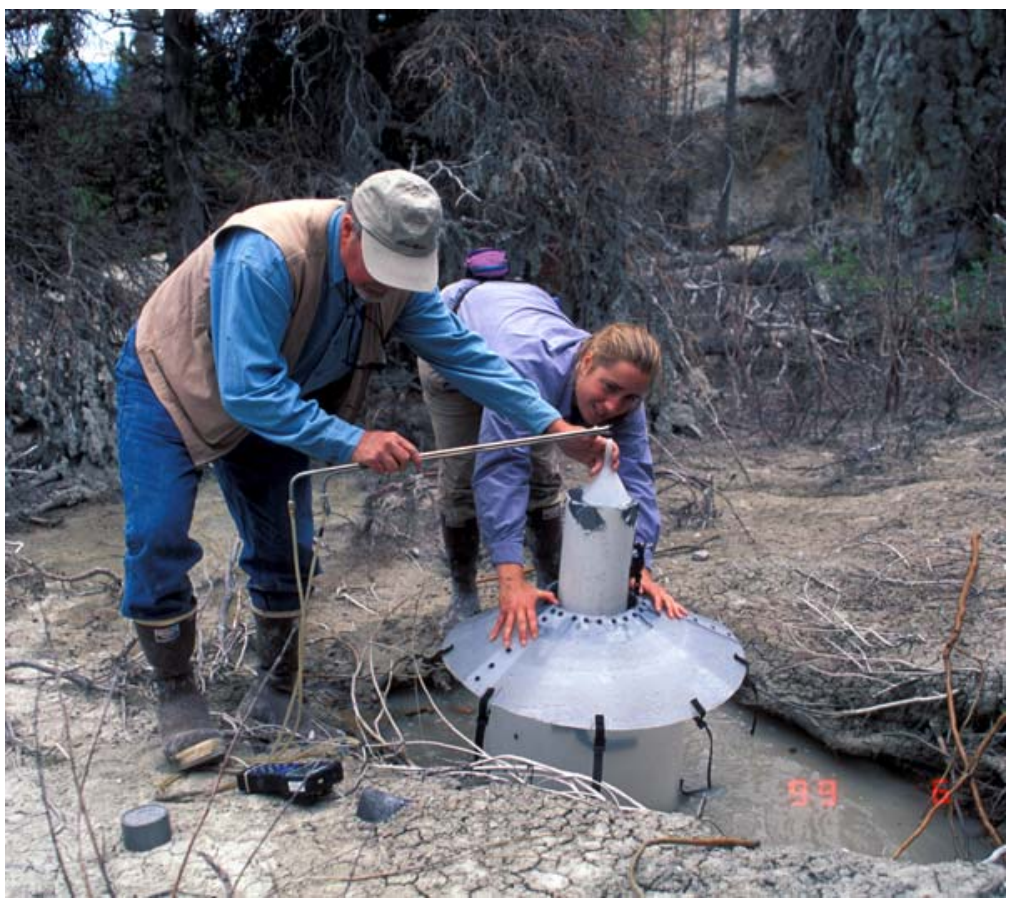

Figure 6. Mike Sorey (USGS) and Cindy Werner (Penn State University) measure $\mathrm{CO}_{2}$ flux at Pit 6 of the Main Vent area (fig. 5). Photo by R.G. McGimsey, June 22, 1999.

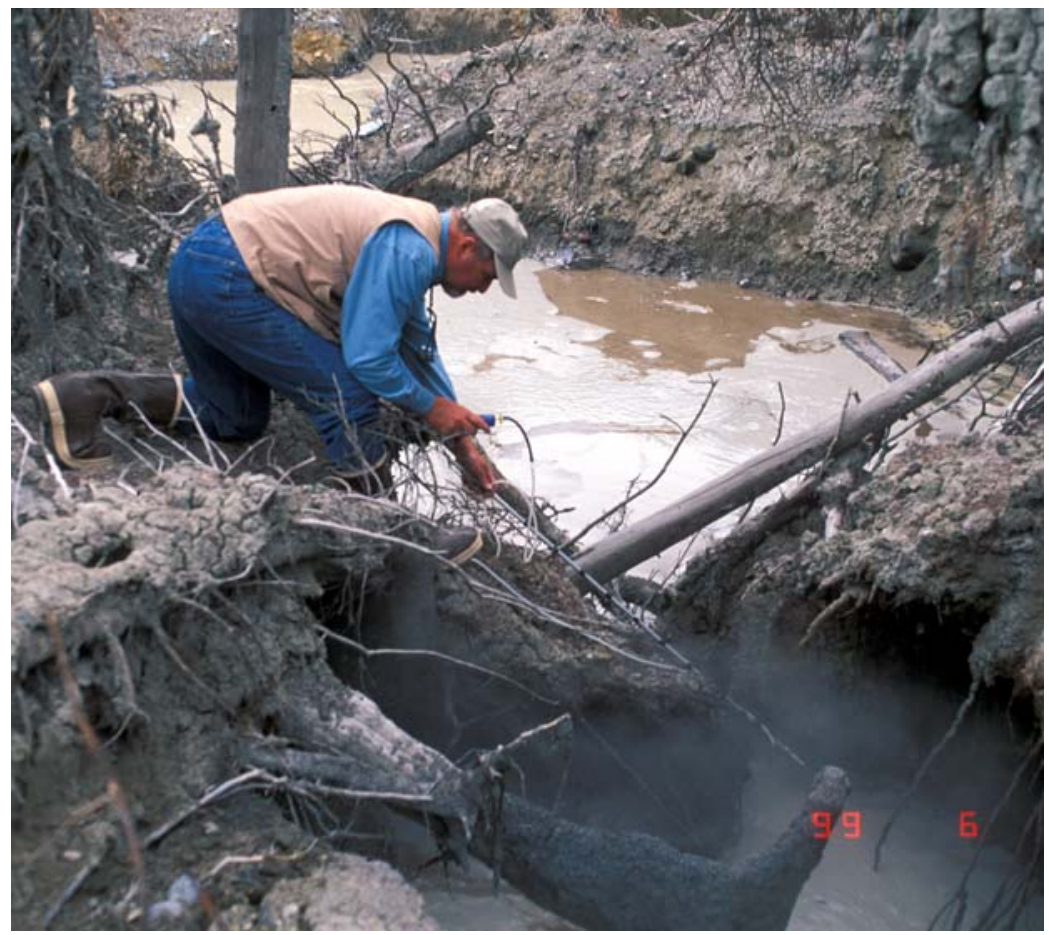

Figure 7. Mike Sorey (USGS) measures $\mathrm{CO}_{2}$ flux in Pit 3, Main vent area (fig. 5). Photo by R.G. McGimsey, June 22, 1999. 


\section{ILIAMNA VOLCANO}

CAVW \#1103-02

$60^{\circ} 02^{\prime} \mathrm{N} 153^{\circ} 04^{\prime} \mathrm{W}$

$10,016 \mathrm{ft}(3,053 \mathrm{~m})$

\section{SUSPECT VOLCANIC ACTIVITY}

Ice and rock avalanche

On July 6, 1999, AVO received a message from the FAA Center Weather Support Unit that a pilot had reported a fresh flow of mud and rock from the upper northeast flank of Iliamna.

Iliamna is an erosionally dissected ice- and snow-covered stratocone that lies $225 \mathrm{~km}$ southwest of Anchorage in the Aleutian Range. No historical eruptive activity has been documented, however, a prominent fumarole field near the summit produces a nearly constant steam plume, which is often mistaken for eruptive activity. The fumaroles high on the south and east-northeast flanks occur where large scars reveal that most of the upper ediface consists of highly altered, unstable rock. The eastern scar has been the source of frequent non-volcanic gravitational collapses that produce mixed avalanches of ice, snow, rock, and mud that typically extend several kilometers down the flank; some are large enough to be visible from the Kenai Peninsula (Neal and others, 1995; McGimsey and Wallace, 1999). Although Iliamna has had no significant activity within the past 200 years, two strong, shallow, seismic swarms in 1996 indicate that the volcano remains restless. AVO maintains a 6-station seismic network on the volcano.

\section{VENIAMINOF VOLCANO \\ CAVW \#1102-07 \\ $56^{\circ} 10^{\prime} \mathrm{N} 159^{\circ} 23^{\prime} \mathrm{W}$ \\ $8,225 \mathrm{ft}(2,507 \mathrm{~m})$}

SUSPECT VOLCANIC ACTIVITY

Extreme discharge and turbid river

On July 30, 1999, AVO received a report from an Alaska Department of Fish and Game $(A D F \& G)$ biologist working at a fish weir on the Chignik River that the West Fork was unusually turbid. An ADF\&G pilot also reported that an abnormal amount of water was discharging from the termini of the glaciers feeding this river, which originate on the east and northeast flanks of Veniaminof Volcano. The biologist and pilot—both experienced in the area—had never before seen this level of discharge and extreme turbidity in the river and were concerned about potential adverse effects on fish. They reported that no unusual steaming or other activity was visible from their camp. There were no further reports. AVO had no seismic instruments on this volcano in 1999. 
Veniaminof is a huge ( $35 \mathrm{~km}$ wide), truncated volcano located $760 \mathrm{~km}$ southwest of Anchorage on the Alaska Peninsula with a spectacular $8 \times 11 \mathrm{~km}$, ice-filled caldera. A breach in the west wall of the caldera drains the basin. A central post-caldera cone is the source of all historic eruptive activity, which is typically strombolian in nature. The last eruption of Veniaminof was in 1993-1995 (Neal and others, 1996; Neal and other, 1995; McGimsey and Neal, 1996). Recent eruptions (e.g. 1983, 1993) have melted large (several square kilometer) holes in the summit glacier with meltwater apparently stored subglacially, since no unusual discharge was noted during the eruptions.

\author{
PAVLOF VOLCANO \\ CAVW \#1102-03 \\ $55^{\circ} 25^{\prime} \mathrm{N} 161^{\circ} 54^{\prime} \mathrm{W}$ \\ $8,262 \mathrm{ft}(2,518 \mathrm{~m})$ \\ SUSPECT VOLCANIC ACTIVITY \\ Summit snow melt and ash dustings; steam plumes
}

An AVO remote-sensing specialist on a commercial flight from Cold Bay to Anchorage on July 13, 1999 noted that the summit of Pavlof was snow-free and that the upper, snow-covered north flank appeared "dirty". A pilot reported on July 30 "ash to 5,000 feet [presumably above the summit]...no eruption". Seismic and satellite data indicated no unusual activity. NWS personnel suggested that strong winds in the area were remobilizing ash deposits on the upper flanks and summit. Steam plumes from the summit were visible from Cold Bay on several occasions.

Pavlof Volcano is a snow-covered, conical, stratocone located near the tip of the Alaska Peninsula (figs. 1a and 1b). It is one of several vents that lie on a northeast-trend extending from the northeast rim of Emmons Lake Caldera, an $18 \times 11 \mathrm{~km}$ Late Quaternary caldera with voluminous postcaldera volcanism continuing to the near present, albeit with no documented historic activity (Wood and Kienle, 1990). Pavlof is the most active volcano in Alaska with over 40 relatively welldocumented historic eruptions, the most recent having occurred September 1996 to January 1997 (Neal and McGimsey, 1997). The eruptive style is typically strombolian fountaining, from vents located near the summit on the upper north and east flanks, with spatter-fed agglutinate flows and minor lahars extending down the flanks. 


\section{SHISHALDIN VOLCANO}

CAVW \#1101-36

$54^{\circ} 45^{\prime} \mathrm{N} 163^{\circ} 58^{\prime} \mathrm{W}$

$9,373 \mathrm{ft}(2,857 \mathrm{~m})$

ERUPTION

Strombolian eruption February-May, 1999

During the summer of 1998, the volcano became seismically restless. Activity slowly escalated and culminated in a subplinian eruption on April 19, 1999 that placed an ash cloud to 45,000 ft ASL $(\sim 13,700 \mathrm{~m})$. The eruption style almost immediately changed to that of vigorous strombolian fountaining (Nye and others, 2002), which characterized the activity for the following six weeks. AVO closely monitored the activity using seismic data, daily imagery from weather satellites, rare local ground and aerial observations, and an airborne thermal instrument. The eruption was deemed over in the last few days of May.

Shishaldin Volcano is a nearly symmetrical stratocone (fig. 8) located in the central portion of the Aleutian arc, about 1,100 km ( 680 mi) southwest of Anchorage near the center of Unimak Island, easternmost of the Aleutian Islands (fig. 8). Subduction along the arc is the most orthogonal, and convergence rate the greatest, along this portion of the central arc. The highest peak in the Aleutians and third most frequently active Alaskan volcano, Shishaldin is largely ice and snow covered and has a small summit crater that sustains a nearly continuous emission of steam. At least 28 eruptions - mostly strombolian ash and steam events-have been reported since 1775 with the latest occurring December 1995-May 1996 (Miller and others, 1998). The nearest community is the small village of False Pass, located $32 \mathrm{~km}$ ( $20 \mathrm{mi}$ ) east-northeast of the volcano. A six-station seismic network was installed on and around Shishaldin by AVO during the summer of 1997. 


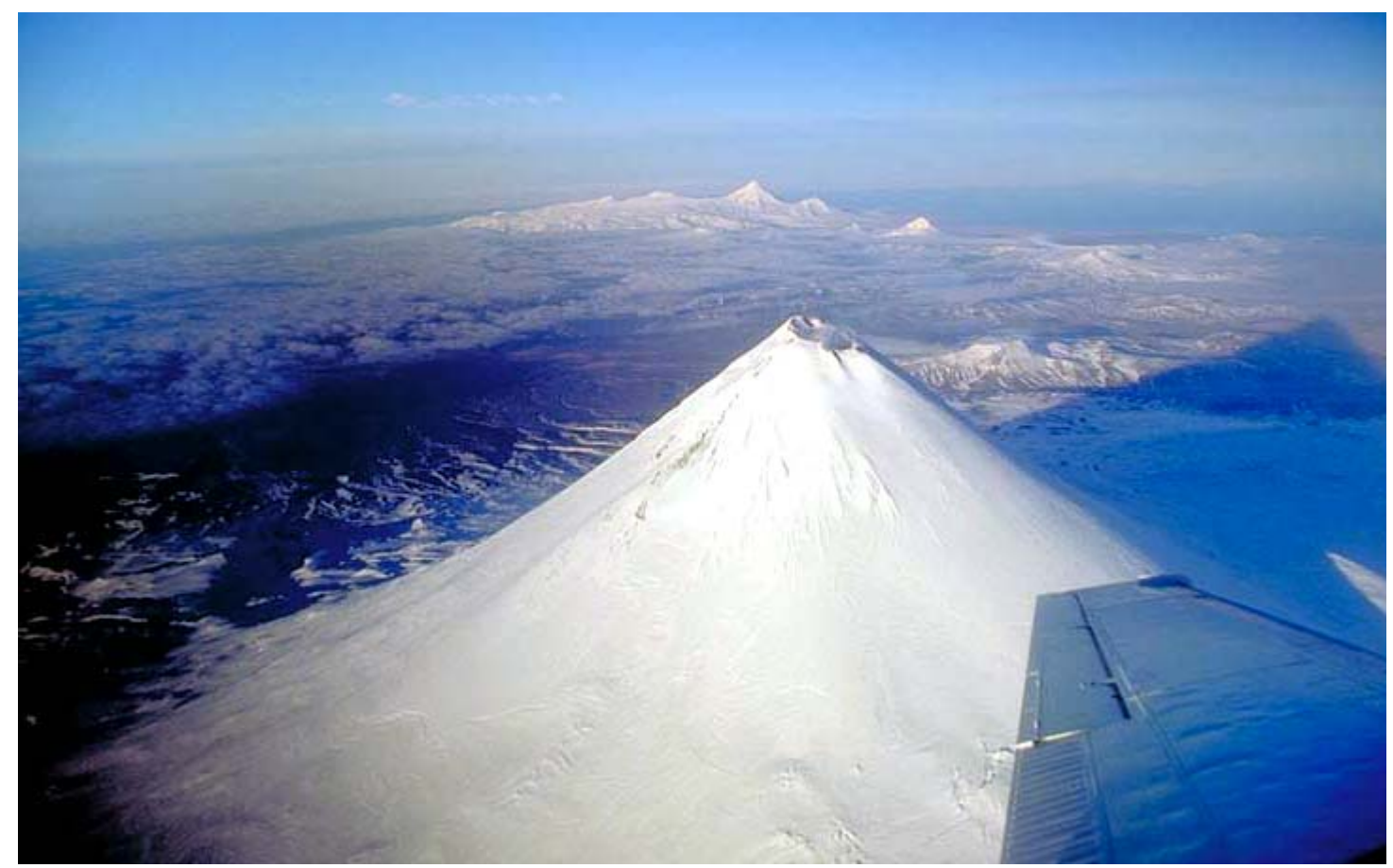

Figure 8. Oblique aerial view from the east of Shishaldin Volcano. Westdahl Volcano in distance. Photo by C.A. Neal, March 27, 1995.

At 10:14 AM AST on January 7, 1999, a shallow, M1.4 earthquake was recorded under Shishaldin Volcano (Jolly and others, 2001). On January 9 at 5:55 PM AST, AVO received a call from National Weather Service (NWS) personnel in Cold Bay reporting that a larger than usual steam plume with possible ash at the base was rising from Shishaldin Volcano to an estimated 10,000 to 15,000 feet ASL and extending several tens of kilometers to the northeast. No anomalous seismicity was occurring and the activity was not visible on Advanced Very High Resolution Radiometer (AVHRR) satellite imagery from 0113Z and 0222Z. A follow-up report from NWS at 6:40 PM AST indicated that the steam plume was somewhat diffuse but still more voluminous than usual.

On February 2, AVO seismologists noted a high level of tiny seismic events occurring beneath the volcano. NWS personnel in Cold Bay reported seeing a "good plume" at Shishaldin on February 9 rising 5,000-6,000 ft. above the vent and trailing to the south. A weak thermal anomaly was also observed on this date. Steaming continued for the next couple of days and a one-pixel thermal anomaly was visible in the AVHRR $1715 Z$ satellite image on February 12. Shishaldin was clearly restless, and AVO announced the activity in the weekly update that morning (Friday, Feb. 12) and warned that while a thermal anomaly persisted, there was a chance of a sudden, low-level ash burst. A pilot reported a steam plume rising 9,000 ft. above the vent on the morning of February 18; this was corroborated by a NWS observer in Cold Bay. AVO seismologists determined on this date that low-level but continuous seismic tremor was occurring at the volcano. This, and the persistence of a thermal anomaly prompted AVO to raise the Level of Concern Color Code from GREEN to YELLOW at 3:15 PM AST (0015 UTC) on Thursday, February 18. [Note, see Table 5 for an explanation of the Level of Concern Color Code] 
Steam activity seemed to wane for the next several weeks. On March 4, a shallow M5.2 earthquake struck 9 miles $(14 \mathrm{~km}$ ) southwest of Shishaldin (Moran and others, 2002). NWS observers in Cold Bay reported that on March 5 the summit crater rim of the volcano was snow-free-an indication of increased heating of the summit; no ash was present on the snow-covered upper flanks. On March 8, AVO reported that the summit vent thermal anomaly had increased over the weekend, seismic tremor was continuing, and that an ash burst could occur with little or no warning.

During the next three weeks — when weather permitted a view-NWS observers in Cold Bay reported that no steam plume was present but the upper flanks were snow-free. The summit vent thermal anomaly persisted, as did low-level seismic tremor. On April 2, a pilot confirmed the snowmelt at the summit.

After nearly two and a half months of precursory activity strong seismic tremor began on April 7 at about 8:00 AM ADT (1600 UTC). AVO raised the Level of Concern Color Code to ORANGE and warned that an explosive ash burst or lava eruption could occur over the next several hours or days. By that afternoon, although the strong seismic tremor had subsided, the Color Code was held at ORANGE and AVO began a 24-hour monitoring effort, which would last until June 18, 1999.

On April 12, with seismicity back down to somewhat-above-background levels since April 7, AVO reduced the Level of Concern Color Code to YELLOW; the summit vent thermal anomaly persisted. Then, late on the night of April 13, seismic tremor increased significantly following a M4.5 earthquake and aftershocks that occurred west of the volcano. AVO raised the Color Code back up to ORANGE the following afternoon, April 14.

Seismic tremor levels began to steadily increase on April 17. On this day, an AVO scientist accompanied the Alaska State Troopers in their Forward-Looking-Infrared-Radiometer (FLIR)equipped twin-engine aircraft on a flight down the Alaska Peninsula. Although a steam cloud obscured the summit area of Shishaldin, FLIR images revealed that energetic strombolian fountaining was occurring with blocks and spatter hurled up to 600 feet $(\sim 200 \mathrm{~m})$ within the vent (figs. $9,10)$. NWS observers and a ship's crew offshore reported that snowmelt had run partway down the northwest flank. 


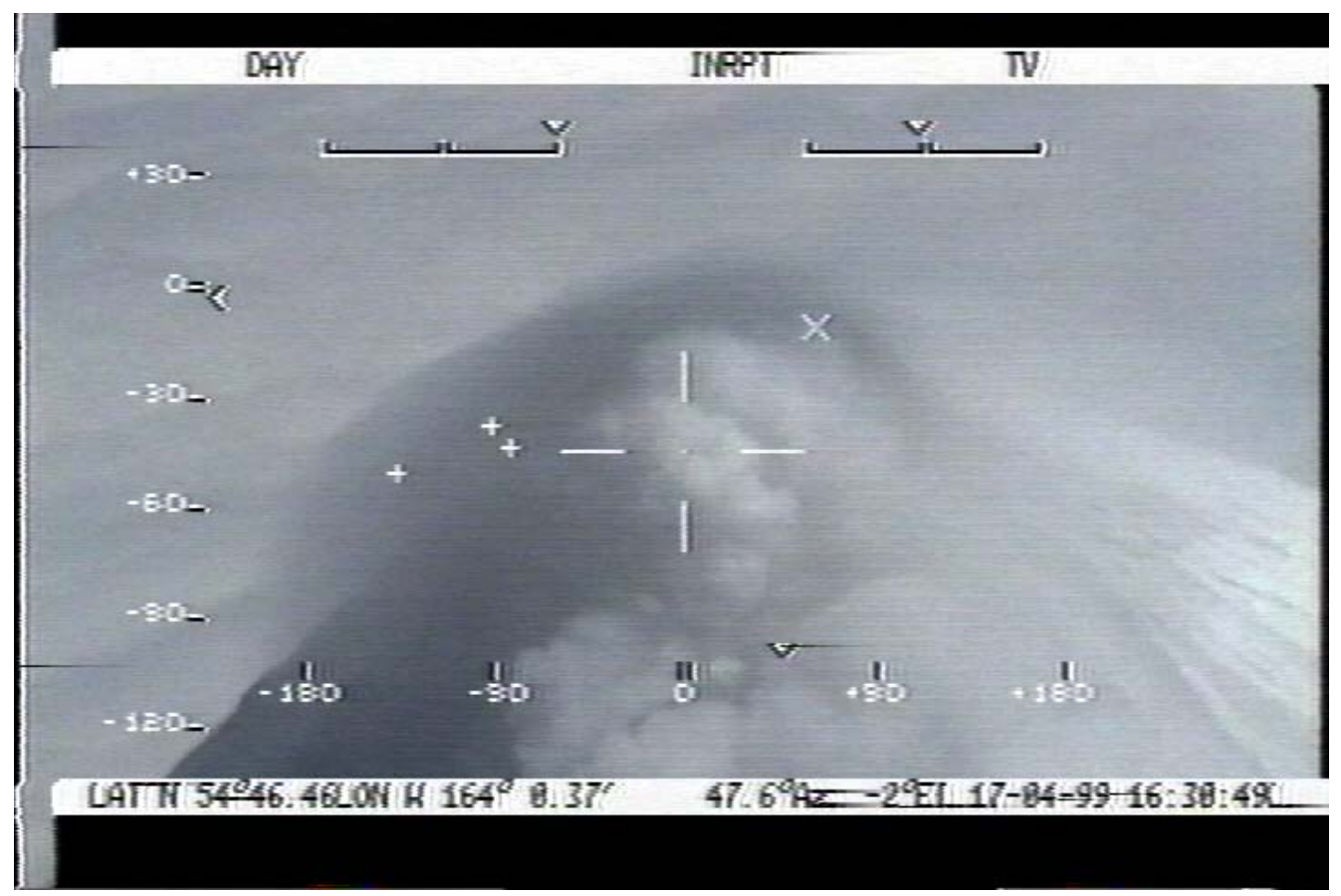

Figure 9a. In the visual image, steam clouds obscure the summit of Shishaldin, April 17, 1999. Photograph courtesy of Alaska State Troopers.

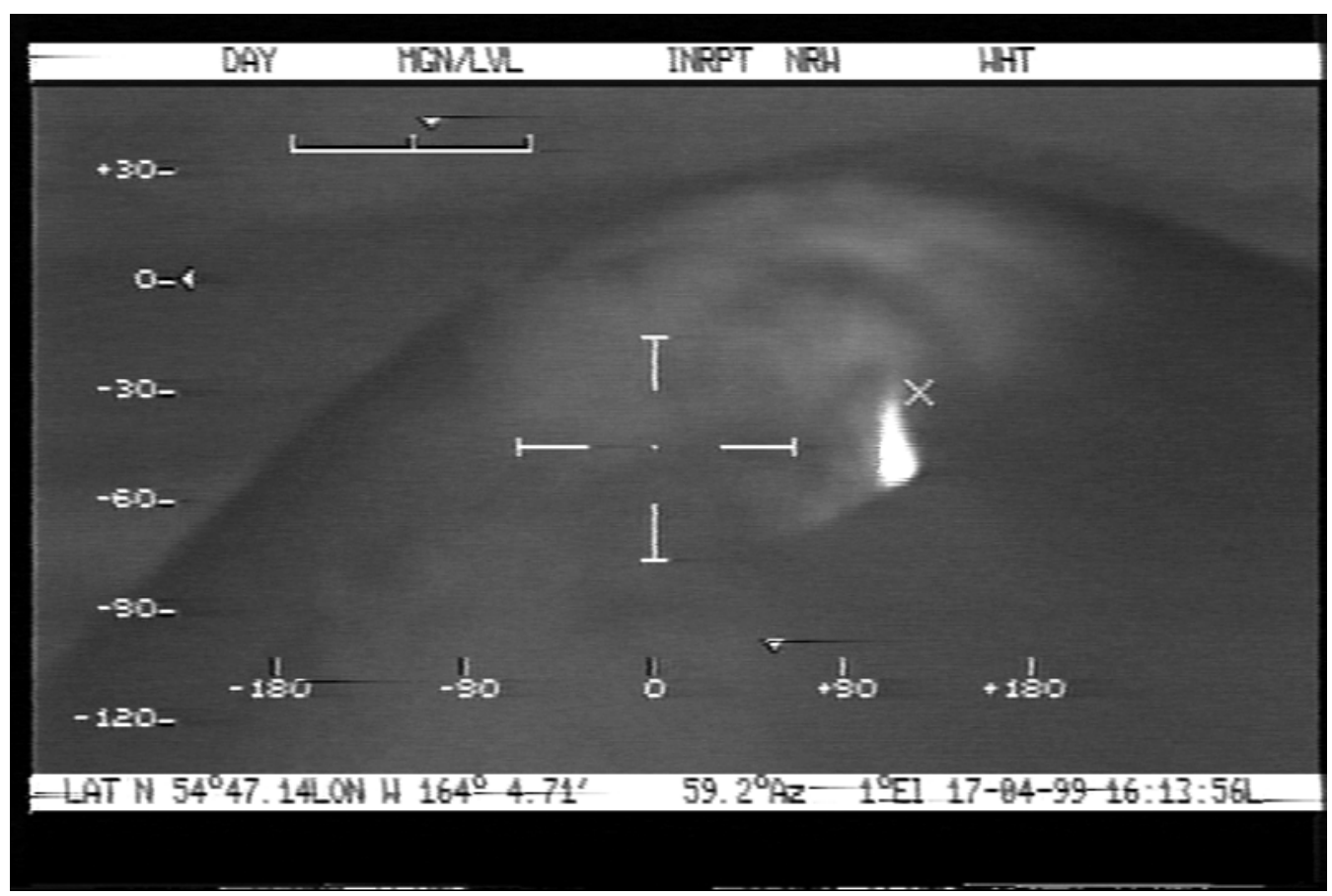

Figure 9b. The FLIR image (white=hot), taken at the same instant as the visual image in 9a, shows strombolian lava fountaining (several hundred meters high) in the summit crater. April 17, 1999. Courtesy of Alaska State Troopers. 


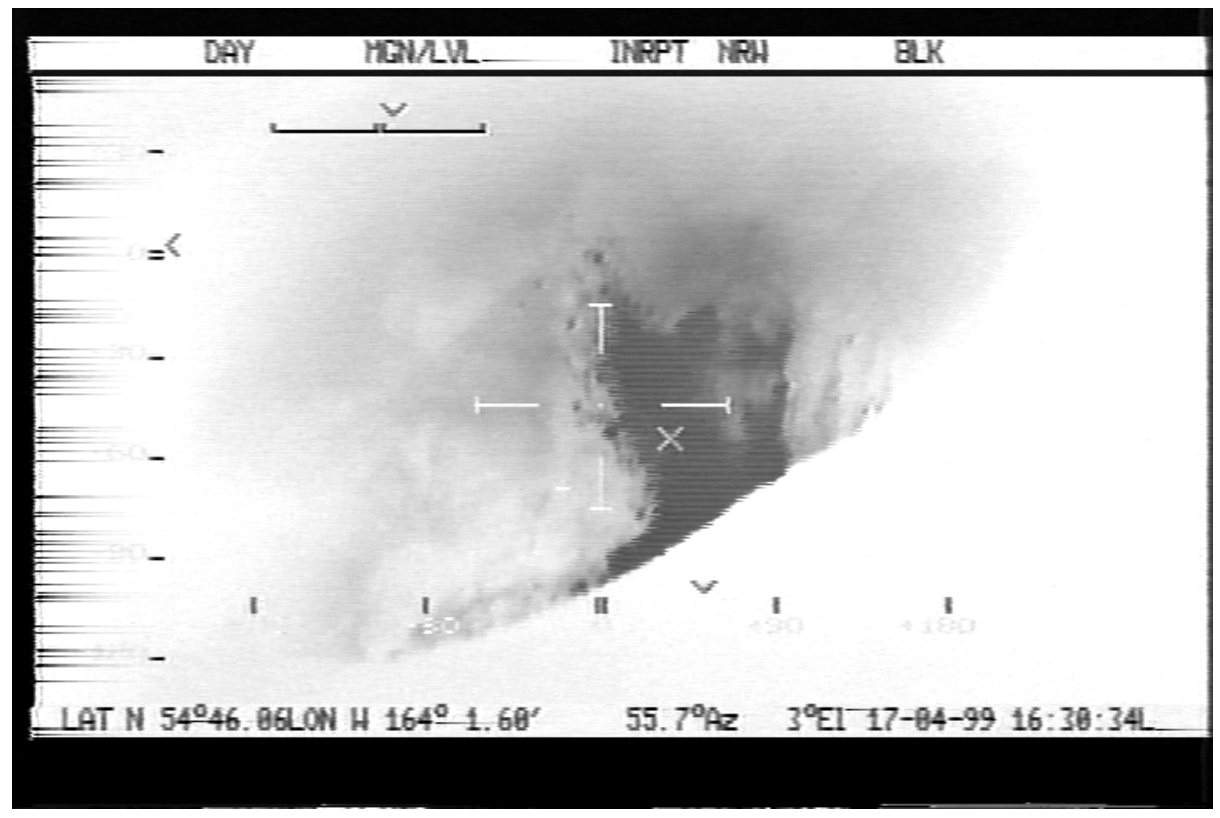

Figure 10. Telephoto zoom FLIR image of lava fountaining (several hundred meters high) in summit crater of Shishaldin. Black = hot April 17, 1999. Photograph courtesy of Alaska State Troopers.

At 11:33 AM ADT (1933 UTC) on April 19, seismic tremor amplitudes dramatically increased and at 11:45 AM a pilot reported seeing a steam and ash plume that rose to 30,000 $\mathrm{ft}(\sim 9,150 \mathrm{~m})$. AVO raised the Color Code to RED at 12:15 PM ADT (2015 UTC) and announced that a significant eruption was in progress. By early afternoon the plume had reached 45,000 ft ( 13,700 m). Satellite data suggests that the plume reached a maximum height of about 56,000 ft. $(17,000 \mathrm{~m})$ (Dave Schneider, oral communication). Ash was dispersed southward at higher altitudes and northward at lower altitudes (fig. 11). 


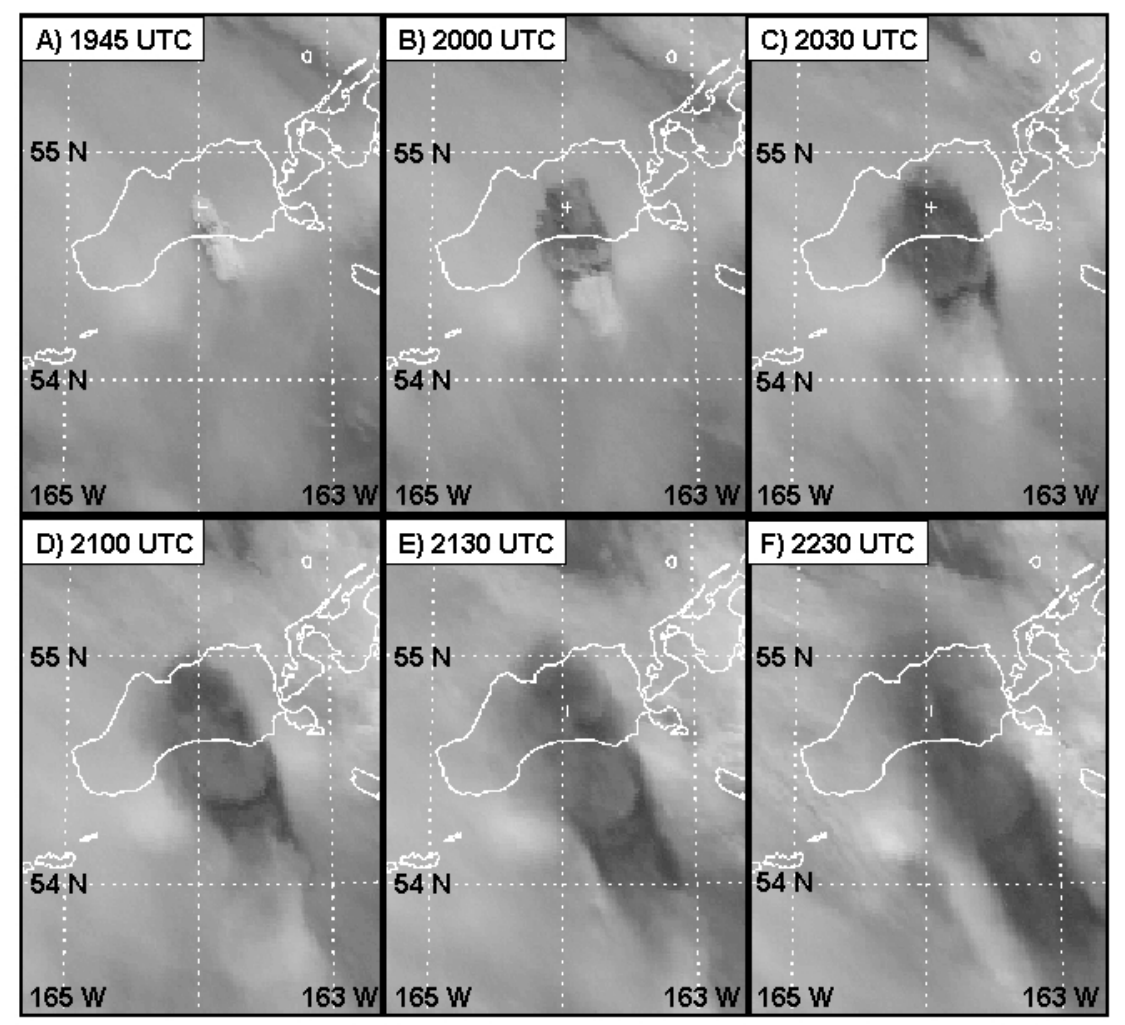

Figure 11. A time series of GOES visible wavelength satellite images showing the development of the April 19, 1999 ash cloud from Shishaldin. Courtesy Dave Schneider (Alaska Volcano Observatory).

The eruption lasted about 7 hours, and by 11 PM on April 19, seismic tremor had substantially decreased although strombolian eruptive activity likely continued based on seismicity. A further abrupt and significant decrease of seismicity in the early morning hours of April 20 indicated that explosive activity had subsided, prompting AVO to lower the Color Code to ORANGE. A thermal anomaly persisted in the summit crater. However, about 4 PM ADT (0000 UTC) on April 20, seismic tremor began to increase again and strengthened about 11 PM ADT (0700 UTC). By midmorning on April 21, seismicity was back up to levels similar to that in the hours prior to the explosive eruption on April 19 prompting AVO to raise the Color Code to RED at 11:15 AM ADT (1915 UTC) and issue a warning that a moderately strong strombolian eruption was likely occurring and that a significant explosive event could occur at any time. Satellite imagery on this day revealed no major ash cloud but a very large thermal anomaly was visible through the night; lava fountaining to a few hundred feet above the summit was observed along with occasional steam and ash clouds under 15,000 ft. ( 4,600 m).

An explosive eruption was not forthcoming and on Thursday morning, April 22, although seismicity continued to fluctuate, the overall level had decreased from that of the previous morning. AVO lowered the Color Code to ORANGE at 10 AM ADT (1800 UTC) April 22. AVO personnel flying with the Alaska State Troopers late that afternoon observed low-level strombolian activity. Seismicity soon began to increase and by 9 PM ADT (0500 UTC), based on rapid increase of tremor levels, an explosive eruption began prompting AVO to again elevate the Color Code to 
RED (9:50 PM ADT, 0550 UTC, April 22). The tremor signals that occurred during the eruptions of Shishaldin Volcano on April 19 and 23 were the strongest ever recorded in the Aleutian Arc by AVO in its 11-year history (Thompson and others, 2002).

About 4 hours later, seismic tremor rapidly diminished heralding an end to this eruptive event. Later that morning AVO reduced the Color Code to ORANGE (7:50 AM ADT, 1550 UTC, April 23). The size of the summit thermal anomaly indicated the continuance of low-level strombolian activity, although no ash clouds were visible on satellite images. Seismicity continued to be relatively low throughout the day. An AVO observer aboard the State Troopers plane documented a short-lived, mildly explosive ash burst that rose to about 15,000 ft ASL ( 4,600 m) (see cover photograph). Also observed was that the flanks were mantled with ash, mudflows, and probable spatter-fed lava flows from earlier eruptive activity (fig. 12).

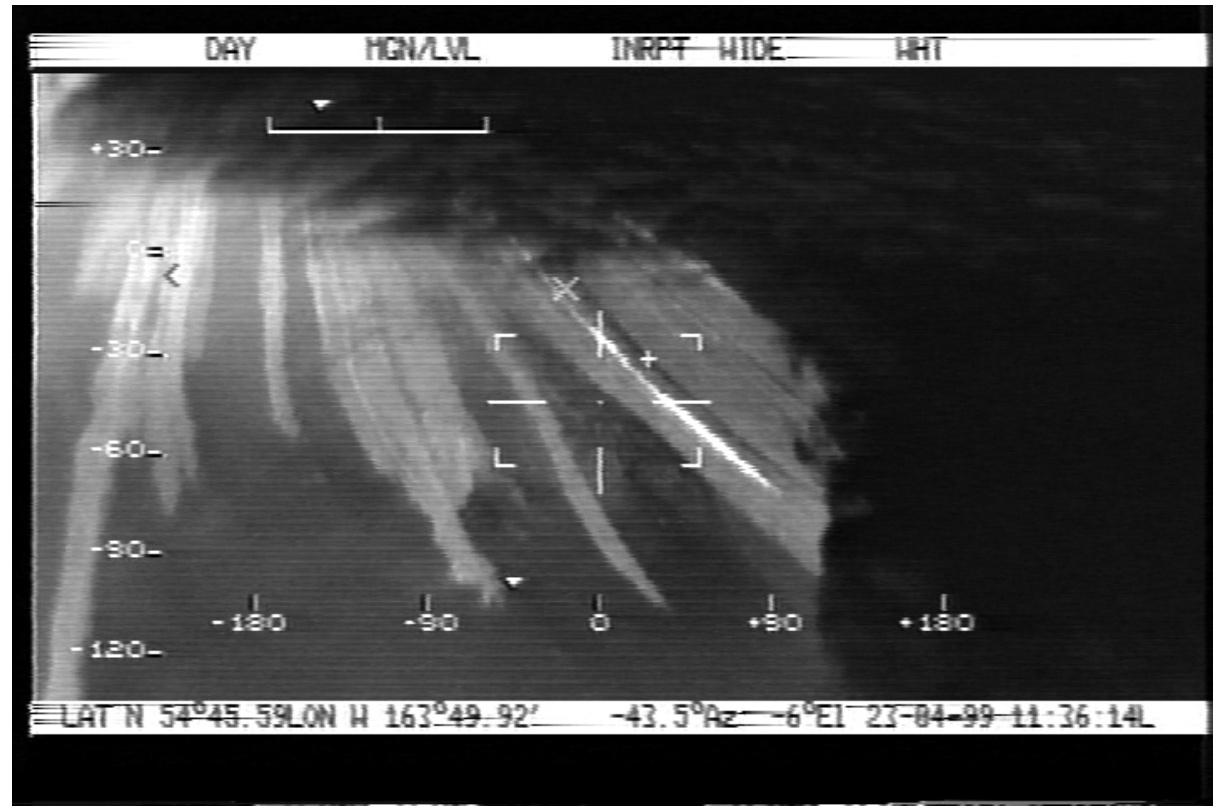

Figure 12. FLIR images (white = hot) showing minor mudflows on the flanks of Shishaldin Volcano. April 23, 1999. Courtesy of Alaska State Troopers.

For the next two days, occasional strombolian eruptions occurred—based on continuation of relatively low seismicity and persistence of the summit thermal anomaly — and on the morning of April 26, a fishing vessel located 40 miles east of the volcano reported light ashfall. Satellite data confirmed a narrow plume extending for more than $100 \mathrm{mi}(161 \mathrm{~km})$ to the northeast and a weak summit thermal anomaly. By April 28, seismicity had declined to levels that indicated that eruptive activity was not likely occurring, no ash clouds had been observed in the past 2 days, and the summit thermal anomaly, which had persisted since early February, was not present on clear satellite images. AVO responded by lowering the Color Code to YELLOW but warning that eruptive activity could resume with little or no warning.

Nothing much changed until the night of May 12 when a weak thermal anomaly appeared on a GOES satellite image and weak seismic tremor was recorded. The following morning, May 13, the crew of a NWS boat at the north end of False Pass observed a small steam and ash burst 
( 10:25 AM ADT, 1825 UTC). A PIREP at 11:15 AM ADT (1955 UTC) confirmed a small plume that rose to about $1,000 \mathrm{ft}(300 \mathrm{~m})$ above the summit. A weak thermal anomaly and lowlevel seismic tremor continued for the next 10 days. Then, late in the evening of May 24 (11:11 PM ADT, 0711 UTC), a PIREP indicated that a plume was present to about 20,000 ft. ASL (6,100 $\mathrm{m})$ above the volcano. Satellite data at 6:59 AM ADT (1459 UTC) on the following morning revealed a narrow, ash-rich steam plume extending 100 miles $(161 \mathrm{~km})$ south from Shishaldin at an altitude of about 15,000 ft. ASL (4,600 m). Low to moderate levels of seismicity continued. AVO raised the Color Code to (9:30 AM ADT, 1730 UTC, May 25) and announced that low-level steam-and-ash eruptions and ash bursts were occurring at the volcano.

For the next several days, narrow, ash-rich plumes were observed via satellite emanating from the volcano and seismicity indicated that short-lived, low-level steam and ash explosions were occurring. A small thermal anomaly persisted. Satellite images on May 28 revealed no evidence of ash plumes or a thermal anomaly and the seismicity declined. An AVO field crew working on the north flank of the volcano reported that only white steam was rising from the summit crater. The lowered level of seismicity and the absence of ash plumes and a thermal anomaly prompted AVO to decrease the Color Code to YELLOW on June 1. This effectively marked the end of the 1999 Shishaldin eruption. The seismicity remained just slightly above normal background levels for the next several weeks and no plumes or thermal anomalies were present. Activity at the volcano had returned to "normal", that is, a nearly continuous low-level steam plume, non-tremor micro-seismicity associated with minor phreatic activity. AVO reduced the Level of Concern Color Code to GREEN on Friday, June 18 (the 14th Color Code change of the eruption, see Table 3), and ended its 24-hour-a-day surveillance of the volcano. The AVO weekly update of volcano activity in Alaska dropped Shishaldin as a feature on Friday, June 25, 1999.

In addition to local minor ash dustings, the eruption produced minor mudflows down the flanks (fig. 12), a significant ash deposit on the south flank, and a lahar deposit down the north flank (fig. 13). The lava produced in this eruption of Shishaldin is evolved basalt of about $49 \% \mathrm{SiO}_{2}(\mathrm{Nye}$ and others, 2002). 


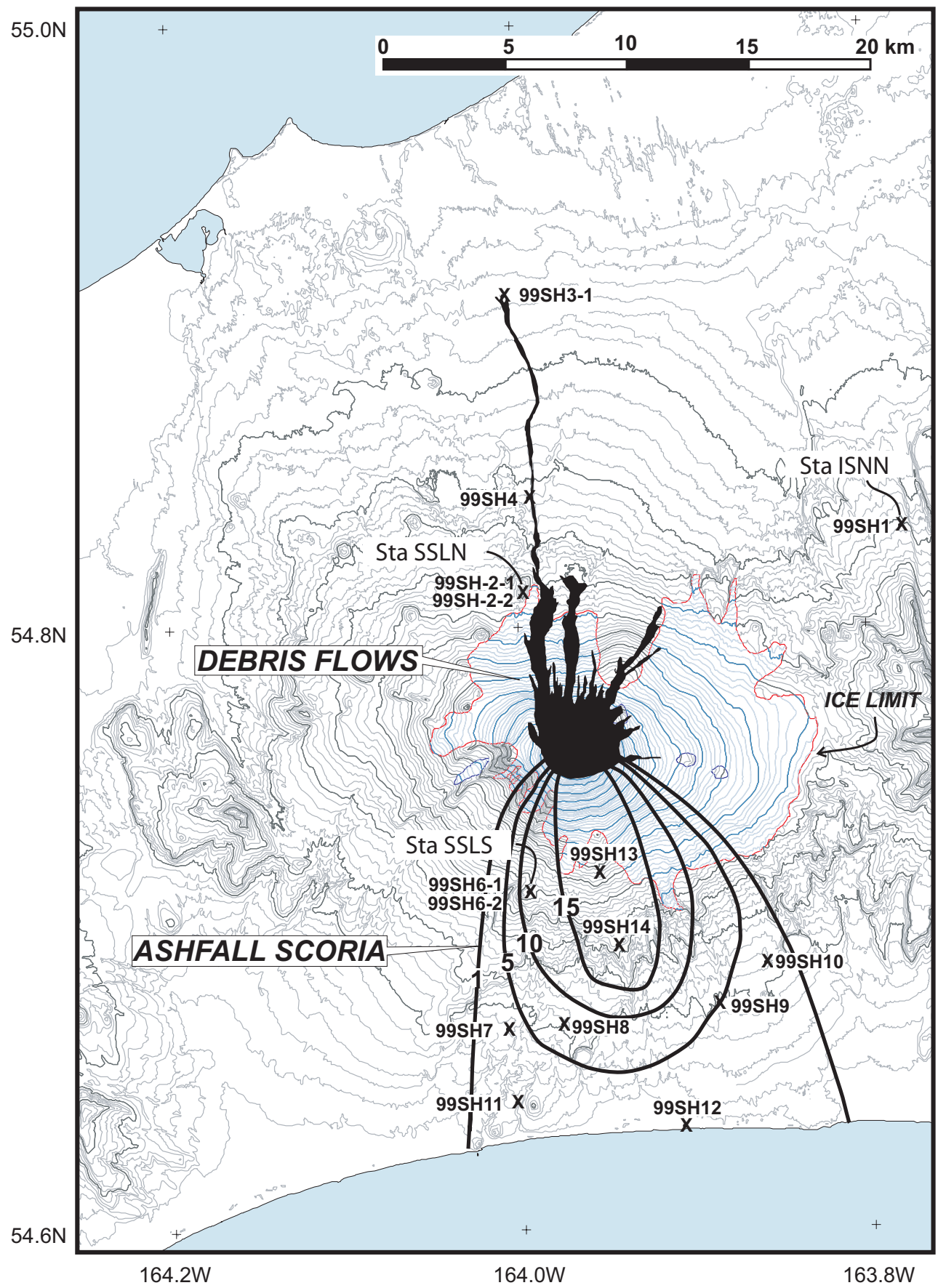

Figure 13. Map of Shishaldin Volcano showing topography, 1999 deposits, and seismic stations. Ash fall deposit isopachs for 1, 5, 10, and $15 \mathrm{~cm}$ are shown with heavy black lines (from Stelling and others, 2002). Debris flow and lahar deposits on the north flank are from a May 25 Landsat-7 image, and are depicted in solid black. Topographic contours of 500-ft beginning at sea level are shown as solid bold lines. The red line is the lower margin of the perennial snow-pack. The dissected cone on the right of map is Isanotski Volcano. Sta ISNN, Sta SSLS and SSLN are seismic stations. Tephra sample sites are marked with an " $x$ " and sample number. From Nye and others (2002). 


\section{VSEVIDOF VOLCANO}

CAVW \#1101-27

$53^{\circ} 08^{\prime} \mathrm{N} 168^{\circ} 41^{\prime} \mathrm{W}$

$7,051 \mathrm{ft}(2,149 \mathrm{~m})$

SUSPECT VOLCANIC ACTIVITY

"black smoke" reported following regional earthquake

On January 28, a resident in Nikolski on Umnak Island called at 4 pm AST to report "black smoke, dark puffing" issuing from the top of nearby Vsevidof Volcano. The weather was cold and clear, and a M6.1 regional earthquake had occurred in the area the previous evening, followed by numerous aftershocks.

AVO received no additional or subsequent reports of activity. Routine examination of satellite data by AVO remote-sensing specialists earlier in the week revealed that indeed a minor steam plume was present at the volcano. The wintertime low sun-angle likely accounts for the reporter's description of "black smoke".

Vsevidof Volcano is a 10-kilometer-wide, symmetrical stratocone situated on the southwest end of Umnak Island; Umnak is westernmost of the Fox Island group in the eastern Aleutian Islands, located $388 \mathrm{~km}$ west of the tip of the Alaska Peninsula. At least seven episodes of minor activity have been historically reported for Vsevidof, the last in 1957 following a series of regional earthquakes when Nikolski residents reported steam and minor ash emission. No seismic instruments were located on Umnak Island in 1999. 


\title{
VOLCANIC ACTIVITY, KAMCHATKA PENINSULA, RUSSIA
}

\author{
NORTH TO SOUTH
}

Active volcanoes on Russia's Kamchatka Peninsula (fig. 14) pose a serious threat to aircraft in the North Pacific. By agreement with the Institute of Volcanic Geology and Geochemistry (IVGG) and the Kamchatka Experimental and Methodical Seismology Department (KEMSD), both Institutes of the Russian Academy of Sciences, AVO assists with global distribution of information about eruptions in Russia (Kirianov and others, 2002). The Kamchatkan Volcanic Eruption Response Team (KVERT), consisting of scientists from both IVGG and KEMSD, issues via email a weekly information release which AVO posts to our website and disseminates via facsimile and email to recipients of our Alaska Volcanoes weekly updates. When volcanic activity at any Kamchatkan volcano intensified requiring notification of aviation interests, KVERT would send updates during the week as needed. Standard KVERT weekly updates - called Information Releases - were traditionally rebroadcast by AVO on Mondays. Beginning in late October of 1999, the schedule was altered to mirror the AVO weekly update schedule and KVERT information releases began to be issued on Fridays.

KVERT monitors most of the frequently active volcanoes in Kamchatka with one or more shortperiod seismometers. In addition, KVERT receives visual reports from scientific observers in the communities of Klyuchi and Kozyrevsk to the north and west of the Klyuchevskoy group of volcanoes. On occasion, KVERT also receives reports from observers near Karymsky Volcano. AVO sends KVERT satellite information on the presence of thermal anomalies or ash plumes when detected as part of AVO's daily satellite monitoring program. This information is interpreted in the context of locally available information and included, as appropriate, in KVERT analyses of eruptive activity. In its 1999 weekly reports, KVERT routinely reported on Sheveluch, Klyuchevskoy, Bezymianny, Karymsky, Avachinsky, and Koryaksky Volcanoes. On the few occasions where seismicity could be attributed to other potentially active volcanoes (e.g. Ushkovsky and Plosky Tolbachik in February, March, and May 1999; Gorely in October, 1999), KVERT reported earthquake activity at these volcanoes as well.

In 1999, AVO processed information about eruptions and volcanic unrest at four Kamchatkan volcanoes characterized by extended periods of unrest. The following summaries contain reported events according to Coordinated Universal Time (UTC), which equals ADT $+8 \mathrm{hrs}$ and AST+9 hrs. The equivalent local Kamchatkan time (herein referred to as Kamchatkan Daylight or Standard time) is 21 hours ahead of Alaska time. This compilation of summary descriptions is derived from a number of sources including KVERT weekly updates (available online at: http:// www.avo.alaska.edu/avo4/updates/kvertarch.htm), AVO internal files and documentation, AVO bimonthly reports, and the Volcanic Activity Reports of the Bulletin of the Global Volcanism Network (available online http://rathbun.si.edu/gvp). 


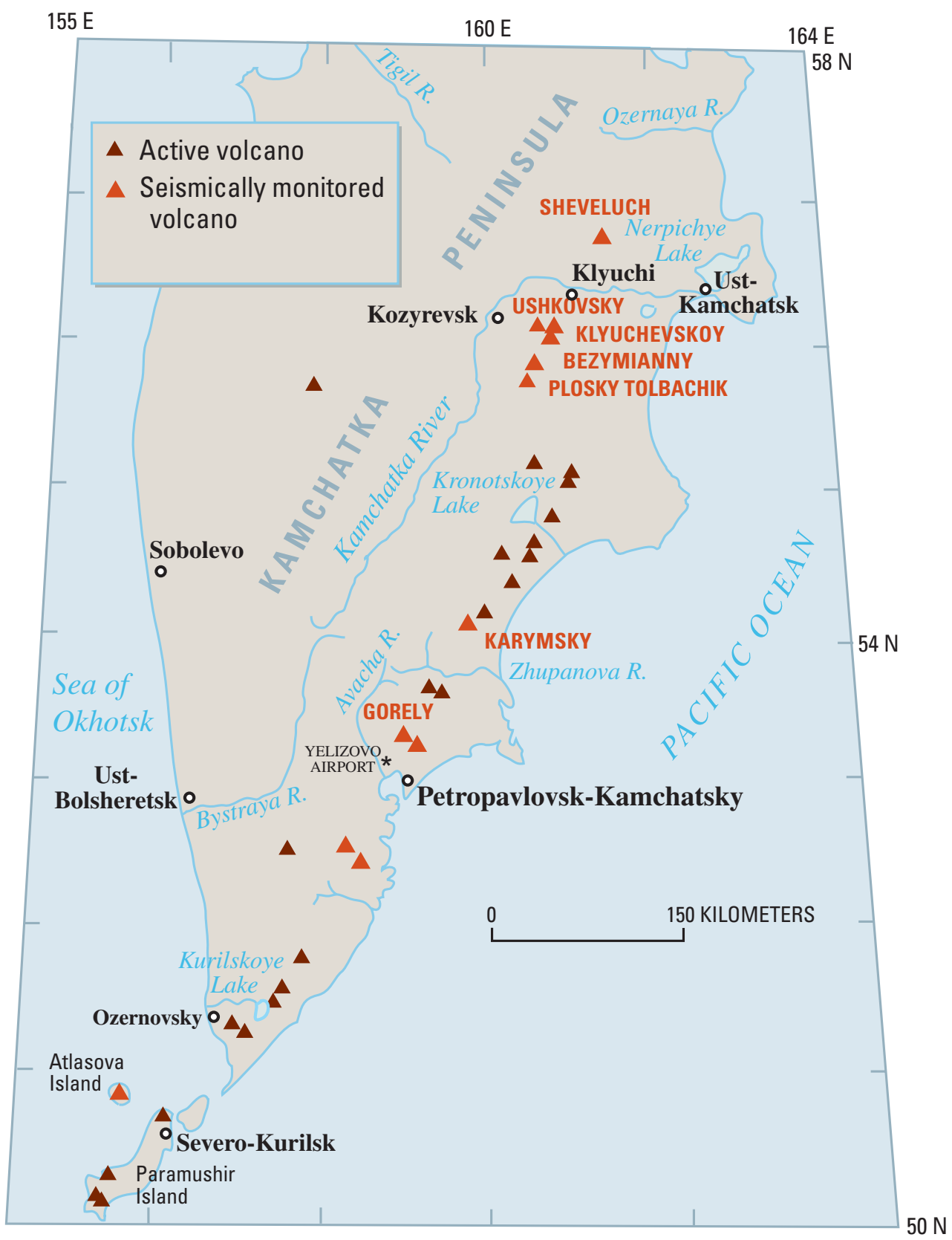

Figure 14. Location map for Kamchatkan volcanoes. Volcanoes discussed in this report are labeled in red text. 


\section{SHEVELUCH VOLCANO}

CAVW \#1000-27

$56^{\circ} 38^{\prime} \mathrm{N} 161^{\circ} 21^{\prime} \mathrm{E}$

$3,283 \mathrm{~m}(10,768 \mathrm{ft})$

Kamchatka Peninsula, Russia

Lava dome growth and instability continued at a low level in 1999. Occasional fumarolic plumes rising 50-1,000 $\mathrm{m}(\sim 160-3,300 \mathrm{ft})$ over the volcano, periods of shallow seismicity and volcanic tremor. A number of short-lived explosive episodes send ash as high as $6,900 \mathrm{~m}$ $(\sim 23,000 \mathrm{ft})$ ASL.

Instability related to growth of the lava dome at Sheveluch Volcano continued at a low level throughout most of 1999. During periods of relative quiet, background seismicity consisted of scattered small earthquakes and occasional tremor beneath the summit crater. With the exception of a brief period in the fall when seismicity was elevated and ash explosions were observed, KVERT maintained Level of Concern Color Code GREEN for most of the year.

During periods of background seismicity, a fumarolic plume rose intermittently over the lava dome to altitudes of $50-1,200 \mathrm{~m}(\sim 160-3,900 \mathrm{ft})$ above the dome. These plumes were visible downwind as far as $5-10 \mathrm{~km}(3-6 \mathrm{mi})$. At times, no plume was present.

Minor, short lived explosions producing transient ash plumes were observed on April 3, April 12, August 15, October 27, November 1, November 24, November 27, and December 2. Most explosions were accompanied by bursts of shallow seismicity; some additional ash-producing explosions suggested by seismicity may have gone unobserved in bad weather or at night. When seen, these ash plumes rose typically to heights of $800-2,000 \mathrm{~m}(\sim 2,600-6,600 \mathrm{ft})$ above the dome and two short-lived explosions sent ash plumes to heights 3,000-3,500 m ( $9,850-11,500 \mathrm{ft}$.) above the dome. The largest explosion likely occurred on October 27 (1232 KDT) when Japan Meteorological Agency detected an ash cloud at an estimated 6,900 m ( 23,000 ft) ASL. Combined with continuing elevated seismicity, this explosion prompted KVERT to raise the Level of Concern Color Code to YELLOW from November 5 till November 19.

During the year, AVO detected thermal anomalies in the vicinity of the dome and observed a number of transient ash-poor and non-ash-bearing plumes on satellite imagery.

Sheveluch Volcano is one of the largest and most active volcanoes in Kamchatka with at least 60 large eruptions during the Holocene (Ponomareva and others, 1998; Belousov and others, 1999). The northernmost active volcano on the Peninsula, historical eruptive activity has been characterized by lava dome growth and explosive collapse, often producing debris avalanches. Its current protracted, episodic phase of lava dome growth began in August of 1980. 


\section{KLYUCHEVSKOY VOLCANO \\ CAVW \#1000-26 \\ $56^{\circ} 03^{\prime} \mathrm{N} 160^{\circ} 38^{\prime} \mathrm{E}$ \\ $4,750 \mathrm{~m}(15,589 \mathrm{ft})$}

Kamchatka Peninsula, Russia

Continuation of 1996-98 eruption. Periods of elevated seismicity, persistent fumarolic plume from summit crater. Explosive events February 5 ( 7,300 m ASL), May 7 ( 7,800 m ASL), July $12(\sim 6,800 \mathrm{~m}$ ASL) send ash as high as $7800 \mathrm{~m}(\sim 25,600 \mathrm{ft})$ ASL.

Klyuchevskoy Volcano remained restless in 1999 with brief periods of elevated seismicity, occasional ash explosions, and strong fumarolic emissions from the summit crater. KVERT changed the level of concern color code from GREEN to YELLOW seven times during the year, largely on the basis of sudden increases in seismicity or direct observation of explosive activity.

As in previous years, earthquakes detected at Klyuchevskoy clustered in two spatial groups: deeper events between $25-30 \mathrm{~km}$ (15-19 mi) below the volcano and shallow events below the summit of the volcano. The level of seismic activity was highly variable over the course of 1999 . Bursts of shallow and deep earthquakes and volcanic tremor were reported by KVERT on several occasions. A particularly strong, shallow earthquake swarm on May 28, accompanied by volcanic tremor, prompted KVERT to raise the level of concern color code to YELLOW for one week.

In addition to periods of gas and steam explosions above the crater, episodes of explosive activity at Klyuchevskoy produced ash plumes visible to scientific staff in Klyuchi. The first occurred on February 5 (ash 2,500 m ( 8,200 ft) above crater) and was followed by an increase in deep earthquake activity. A series of explosions in early May sent ash as high as $3 \mathrm{~km}$ above the volcano ( 26,000 ft ASL). On May 7, explosions became more frequent (every 3 minutes) and sent ash 3 $\mathrm{km}(\sim 9,800 \mathrm{ft})$ above the volcano and $30 \mathrm{~km}(18 \mathrm{mi})$ downwind. Intermittent explosions continued through May 9. Slightly less energetic ash and gas explosions were again observed on July 12 , sending ash as high as $2 \mathrm{~km}(\sim 6,600 \mathrm{ft})$ above the volcano. Beginning in mid-August, explosions of steam and volcanic gas rising 50-100 $\mathrm{m}(\sim 160-330 \mathrm{ft})$ above the crater, but devoid of significant ash, were frequently reported. During periods of quiet, an intermittent fumarolic plume ascended $50-2,700 \mathrm{~m}(\sim 160-\sim 8,900 \mathrm{ft})$ above the summit and trailed downwind as much as 40 $\mathrm{km}(24 \mathrm{mi})$.

Throughout 1999, AVO closely monitored satellite imagery of the Klychevskoy area, shared results with KVERT, and disseminated eruption information to the FAA and NWS. Routine AVO satellite analysis on a number of occasions discerned non-ash bearing plumes from Klyuchevskoy.

Klyuchevskoy is a classic stratovolcano and, at 4,750 m (15,580 ft), the highest of the active European and Asian volcanoes. It is frequently active with vulcanian to strombolian explosions and occasional lava flows from the main vent in the summit crater or from flank vents (Khrenov and 
others, 1991). Explosive eruptions are recorded in nearly every decade and at multiple times during most years since the early 1700s (Simkin and Siebert, 1994). Prior to 1999, the last most significant eruption was September 30-October 1, 1994.

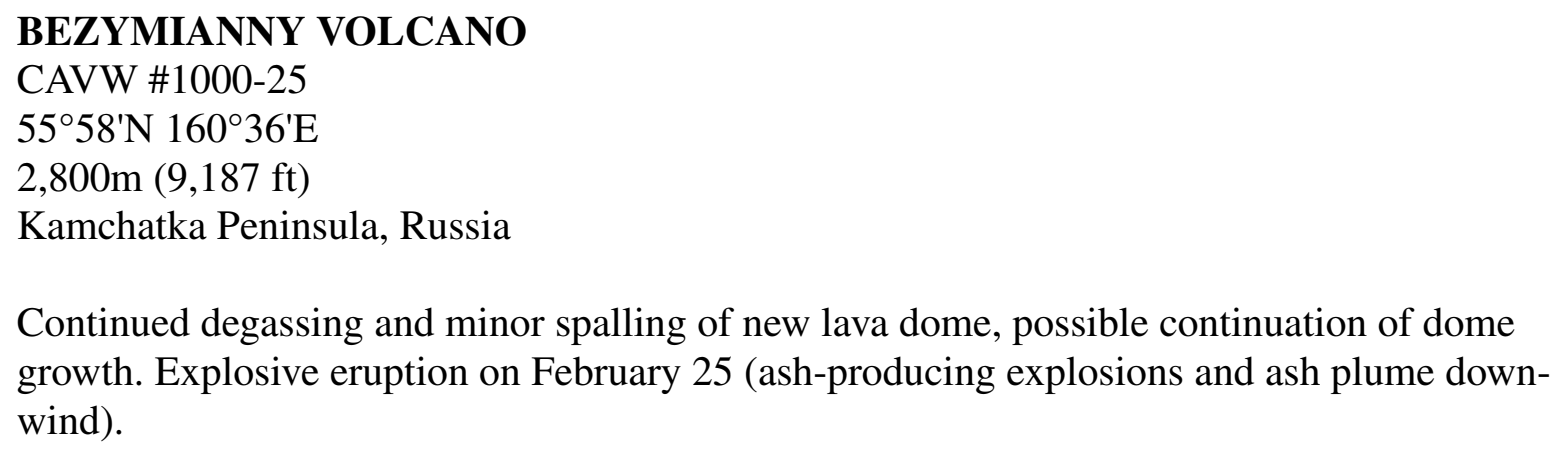

Bezymianny Volcano was relatively quiet for most of 1999. KVERT maintained Level of Concern Color Code GREEN for the entire year with the exception of a two-week period in late February when YELLOW was declared.

The most significant activity at Bezymianny during 1999 occurred in late February. AVO satellite analysis detected a persistent thermal anomaly at the volcano on February 13, an observation that was relayed to KVERT. Combined with observations of increasing shallow seismicity and possible rock avalanches, KVERT raised the level of concern color code to YELLOW on February 15. Seismicity suggested possible avalanches from the dome over the next week. On February 17, AVO detected a faint plume from Bezymianny extending $150 \mathrm{~km}(90 \mathrm{mi})$ southeast on satellite imagery. AVO tracked the growth of the thermal anomaly and, following the onset of tremor on February 25 followed by several significant, seismically detected explosions, KVERT raised the level of concern color code to ORANGE. Observers reported an ash plume rising $5 \mathrm{~km}(\sim 16,000$ $\mathrm{ft})$ above the volcano to an altitude of about $7.5 \mathrm{~km}(\sim 25,000 \mathrm{ft})$ ASL. Satellite images tracked an ash-rich plume extending southeast more than $115 \mathrm{~km}$ (70 mi) (fig. 15). Over the next two days, the cloud was discernable on images as far as $1500 \mathrm{~km}(930 \mathrm{mi})$ southeast of Bezymianny. Explosive activity of the volcano continued for one day and on February 26, KVERT lowered the level of concern color code to YELLOW. During the following two weeks, seismicity at Bezymianny declined, the thermal anomaly decreased in intensity, and KVERT reverted to level of concern color code GREEN on March 9. 


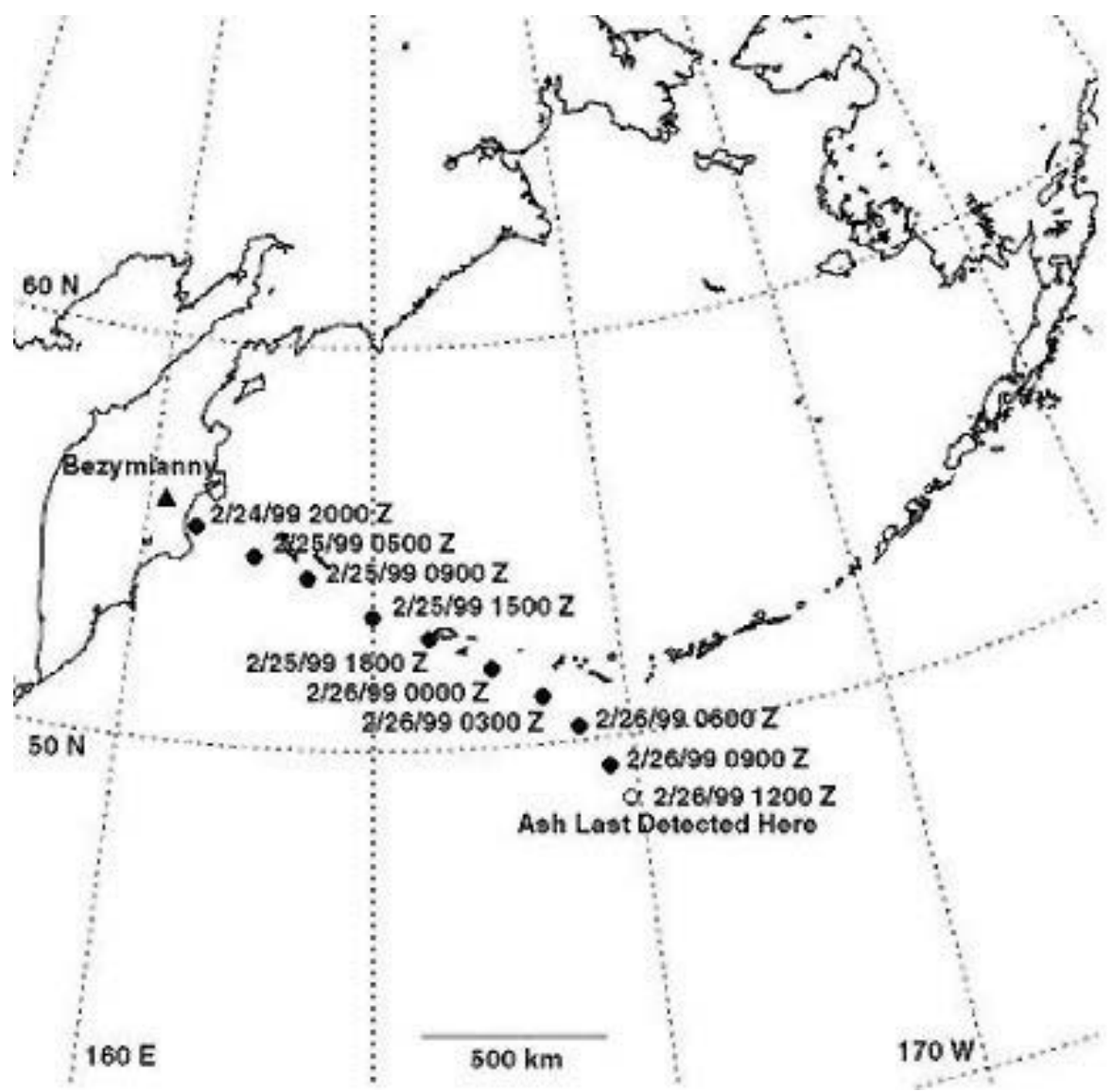

Figure 15. Track of ash plume from eruption of Bezimianny on February 24, 1999. Image combines data from AVHRR, GMS, and GOES satellites.

For the remainder of 1999 , little or no seismicity was detected at the volcano. A fumarolic plume rose intermittently $40-2,000 \mathrm{~m}(\sim 130-6,600 \mathrm{ft})$ above the dome and trailed as far as $40 \mathrm{~km}(25 \mathrm{mi})$ downwind. AVO detected thermal anomalies in the vicinity of the lava dome throughout much of the year. Occasional minor, ash-poor or non-ash bearing plumes were detected by AVO from January - March and again in August.

In October 1955, Bezymianny Volcano emerged from a 900-1,000 year period of quiescence commencing an explosive eruption that culminated on March 30, 1956, with the catastrophic failure of the eastern flank and debris avalanche and lateral blast similar to what occurred at Mount St. Helens in 1980 (Voight and others, 1981). Since then, lava extrusion has produced a dome that periodically collapses generating pyroclastic flows and short-lived ash plumes (Girina and others, 1993; Belousov and others, 2002; Smithsonian Institution, 1995). Bezymianny is one of the most active volcanoes on the Kamchatka Peninsula. 


\section{KARYMSKY VOLCANO}

CAVW \#1000-13

$54^{\circ} 03^{\prime} \mathrm{N} 159^{\circ} 27^{\prime} \mathrm{E}$

$1,486 \mathrm{~m}(4,876 \mathrm{ft})$

Kamchatka Peninsula, Russia

Continuation of 1996-98 activity; low-level vulcanian and strombolian eruptions, explosions, degassing, active lava flow.

Low-level vulcanian and strombolian eruptive activity continued at Karymsky Volcano throughout 1999 (fig. 16). With the exception of a brief period in early August and during the final week of December when KVERT reverted to GREEN, a level of concern color code of YELLOW was in effect for most of the year.

Using seismic records and information from local scientific observers, KVERT tracked periods of intermittent explosions and production of ash-poor plumes from the summit crater of Karymsky. The frequency of explosions began the year at a rate of 300-400 per day. Over the course of the year, with a few exceptions, this rate of explosive events generally declined. By mid-October several tens of explosions per day were recorded. This number diminished further to only a few per day by year's end.

Some explosions or gas emissions from the volcano were particularly vigorous and produced plumes containing ash. On February 10, a pilot reported ash up to $5 \mathrm{~km} \mathrm{(} \mathrm{16,000} \mathrm{ft)} \mathrm{ASL;} \mathrm{this}$ plume may have been related to a vigorous gas emission detected seismically. 


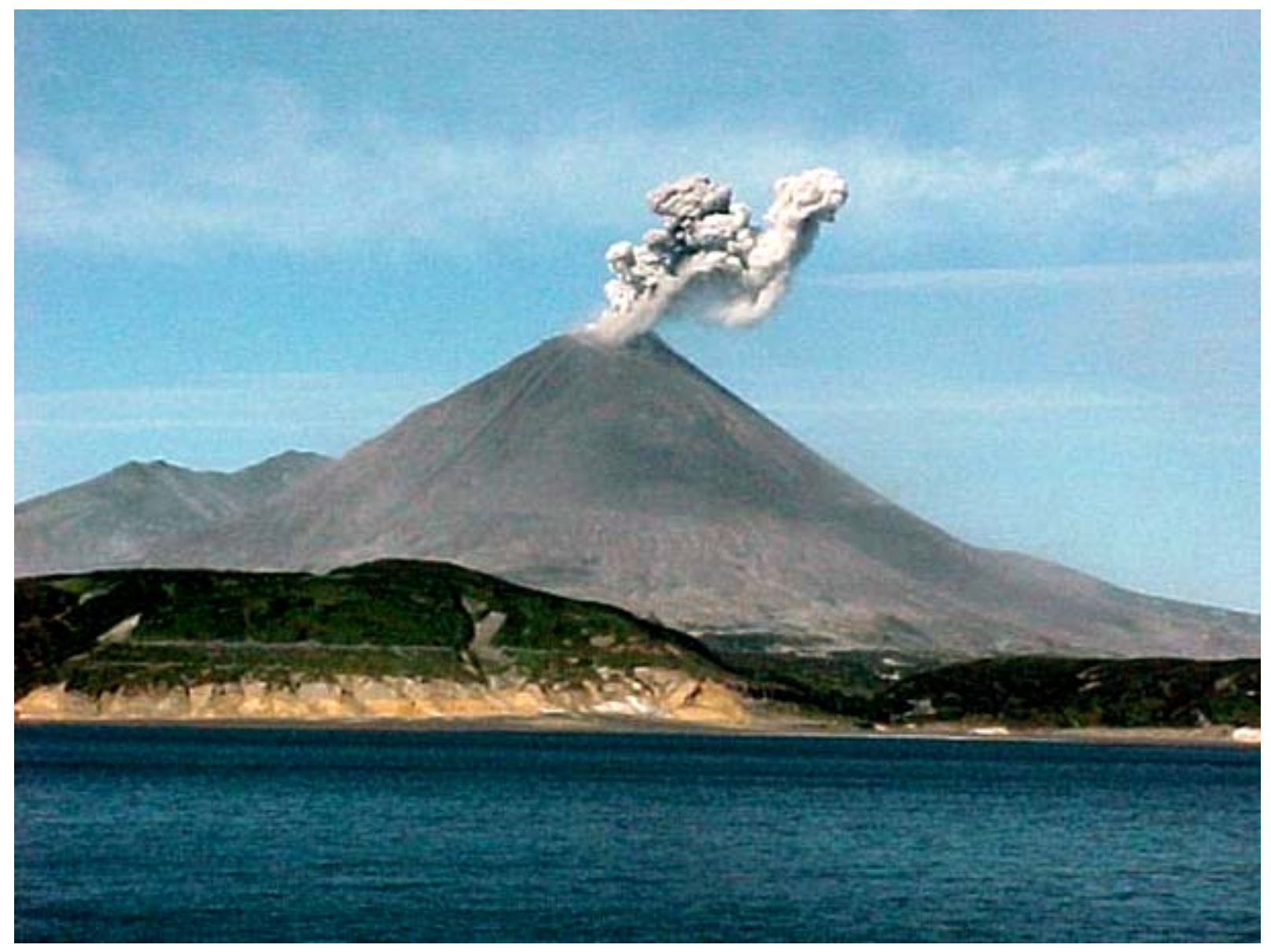

Figure 16. Ash burst from Karymsky Volcano. Photograph by John Eichelberger, August, 1999.

Tourists visited the volcano between July 8 and 10 and reported a viscous lava flow emanating from a collapsed section of the summit crater wall. (Smithsonian Institution, 1999) This same group reported a series of explosions on July 9 that covered the volcano in ash. Blocks as large as a cubic meter showered onto the upper edifice and rolled to the foot of the cone. They also reported an active lava flow, although its position on the volcano is unclear in published reports. KVERT staff visited the volcano in early September and documented pulsing explosions from the summit at a rate of one every 10-20 minutes with plumes rising 300-1,000 $\mathrm{m}(\sim 980-3,300 \mathrm{ft})$ above the crater.

In addition to explosive signals from the volcano recorded by the sole station near Karymsky, at least one episode of earthquake activity occurred in the vicinity of Karymsky Lake, $6 \mathrm{~km}(\sim 4 \mathrm{mi})$ distant. During the opening phase of eruptive activity in 1996, explosive vents were active beneath the northern end of Karymsky Lake (Belousov and Belousov, 2001).

In its routine analysis of satellite imagery of the Kamchatkan Peninsula, AVO detected thermal anomalies and occasional ash-poor plumes at Karymsky for much of the year. The thermal anomaly was particularly persistent from August through December, and likely represented a combination of signatures from the active lava flow and intermittent vulcanian and strombolian bursts 
from the summit crater. A faint, ash-poor plume visible $50 \mathrm{~km}$ (31 mi) downwind from Karymsky accompanied the February 15 thermal anomaly. In mid-August, a plume extending $75 \mathrm{~km}(47 \mathrm{mi})$ downwind was detected by satellite.

Explosive and effusive-explosive eruptions of andesitic tephra and lava flows alternating with periods of repose are typical of eruptive activity Karymsky (Ivanov and others, 1991). The current phase of unrest began with increasing seismicity below the volcano in mid-April, 1995, culminating in an explosive eruption that began on January 1, 1996, at the north end of Karymsky Lake and then shifted to the volcano's summit (Belousov and Belousov, 2001). For the remainder of 1996, periods of explosive eruptions of ash and small blocks alternated with periods of lava flow production (Neal and McGimsey, 1997). The eruption continued intermittently through 1997-98. Karymsky usually issues a continuous steam plume and is the most active volcano on the Kamchatkan Peninsula (Simkin and Siebert, 1994). 


\section{REFERENCES}

Belousov, A., Belousova, M., Voight, B., 1999, Multiple edifice failures, debris avalanches and associated eruptions in the Holocene history of Shiveluch volcano, Kamchatka, Russia: Bulletin of Volcanology, v. 61, n. 5, p. 324-342.

Belousov, A., Voight, B., Belousova, M., and Petukhin, A., 2002, Pyroclastic surges and flows from the 8-10 May 1997 explosive eruption of Bezymianny volcano, Kamchatka, Russia: Bulletin of Volcanology, v. 64, p. 455-471.

Belousov, A. and Belousov, M., 2001, Eruptive process, effects, and deposits of the 1996 and the ancient basaltic phreatomagmatic eruptions in Karymsky lake, Kamchatka, Russia: Special Publications International Association of Sedimentology, v. 30, p. 35-60.

Girina, O.A., Bogoyavlenskaya, G.E., and Demyanchuk, Yu. V., 1993, Bezymyannyi eruption of August 2, 1989: Volcano Seismology, v. 15, n. 2, p. 135-144.

Ivanof, B., Braitseva, O.A., and Zubin, M.I., 1991, Karymsky Volcano, Chapter 21 in: Active Volcanoes of Kamchatka, S. A. Fedotov and Yu. P. Masurenkov, (eds.), Moscow Nauka Publishers (Moscow), Volume 2, p. 202-203.

Jolly, A.D., Stihler, S.D., Power, J.A., Lahr, J.C., Paskievitch, J.F., Tytgat, G., Estes, S., Lockhart, A.B., Moran, S.C., McNutt, S.R., Hammond, W.R., 2001, Catalog of earthquake hypocenters at Alaskan volcanoes January 1, 1994 through December 31, 1999: U.S. Geological Survey OpenFile Report 01-189, 22 p. Also online: http://geopubs.wr.usgs.gov/open-file/of01-189/.

Kirianov, Vladimir Yu., Neal, Christina A., Gordeev, Evgenii I., and Miller, Thomas P., 2002, KVERT (Kamchatkan Volcanic Eruptions Response Team): U.S. Geological Survey Fact Sheet 064-02 in English and Russian. Also online: http://geopubs.wr.usgs.gov/fact-sheet/fs064-02/.

Khrenov, A.P., Dvigalo, V.N., Kirsanov, S.A., Fedotov, Gorel'chik, V.I., and Zharnov, N.A., 1991, Klyuchevskoy Volcano, Chapter 6 in: Active Volcanoes of Kamchatka, S.A. Fedotov and Yu. P. Masurenkov, (eds.), Moscow Nauka Publishers (Moscow), Volume 1, p. 146-163.

McGimsey, R.G., and Neal, C.A., 1996, 1995 Volcanic activity in Alaska: Summary of events and response of the Alaska Volcano Observatory: U.S. Geological Survey Open-File Report 96738, $22 \mathrm{p}$.

McGimsey, R.G., and Wallace, K., 1999, 1997 Volcanic Activity in Alaska and Kamchatka: Summary of events and response of the Alaska Volcano Observatory: U.S. Geological Survey OpenFile Report 99-448, 42 p.

Miller, T.P., McGimsey, R.G., Richter, D.H., Riehle, J.R., Nye, C.J., Yount, M.E., and Dumoulin, J.A., 1998, Catalog of the historically active volcanoes of Alaska: U.S. Geological Survey OpenFile Report 98-582, 104 p. 
Moran, S.C., Stihler, S.D., and Power, J.A., 2002, A tectonic earthquake sequence preceding the April-May 1999 eruption of Shishaldin Volcano, Alaska: Bulletin of Volcanology, v. 64, p. 520524.

Neal, C.A., Doukas, M.P., and McGimsey, R.G., 1995, 1994 Volcanic activity in Alaska: Summary of events and response of the Alaska Volcano Observatory: U.S. Geological Survey OpenFile Report 95-271, 18 p.

Neal, C.A., McGimsey, R.G., and Doukas, M.P., 1996, 1993 Volcanic activity in Alaska: Summary of events and response of the Alaska Volcano Observatory: U.S. Geological Survey OpenFile Report 96-24, 21 p.

Neal, C.A., and McGimsey, R.G., 1997, 1996 volcanic activity in Alaska and Kamchatka: Summary of events and response of the Alaska Volcano Observatory: U.S. Geological Survey OpenFile Report 97-433, 34 p.

Nichols, D.R., and Yehle, L.A., 1961, Mud volcanoes in the Copper River Basin, Alaska, in: Raasch, G.O., ed., Geology of the Arctic: International Symposium on Arctic Geology, 1st, Calgary, 1960, Proceedings, v. 2, p. 1063-1087.

Nye, C.J., Keith, T.E.C., Eichelberger, J.C., Miller, T.P., McNutt, S.R., Moran, S., Schneider, D.J., Dehn, J., and Schaefer, J.R., 2002, The 1999 eruption of Shishaldin Volcano, Alaska: Monitoring a distant eruption: Bulletin of Volcanology, v. 64, p. 507-519.

Ponomareva, Vera V., Pevzner, Maria M., and Melekestsev, Ivan V., 1998, Large debris avalanches and associated eruptions in the Holocene eruptive history of Shiveluch Volcano, Kamchatka, Russia: Bulletin of Volcanology, v. 59, n. 7, p. 490-505.

Richter, D.H., Rosenkrans, D.S., and Steigerwald, M.J., 1995, Guide to the volcanoes of the western Wrangell Mountains, Alaska: U.S. Geological Survey Bulletin 2072, 31 p.

Richter, D.H., Symonds, R.B., Rosenkrans, D.S., McGimsey, R.G., Evans, W.C., and Poreda, R.J., 1998a, Report on the 1997 activity of Shrub mud volcano, Wrangell-St. Elias National Park and Preserve, South-central Alaska: U.S. Geological Survey Open-File Report 98-128, 13 p.

Richter, D.H., McGimsey, R.G., and Rosenkrans, D.S., 1998b, Addendum to U.S. Geological Survey Open-File Report 98-128, 3 pp.

Sorey, M.L., Werner, C. McGimsey, R.G., and Evans, W.C., 2000, Hydrothermal activity and carbon-dioxide discharge at Shrub and Upper Klawasi Mud volcanoes, Wrangell Mountains, Alaska: U.S. Geological Survey Water-Resources Investigations Report 00-4207, 15 p.

Simkin, T., and Siebert, L., 1994, Volcanoes of the world, Tucson, Arizona, Geoscience Press, Inc., $349 \mathrm{p}$.

Smithsonian Institution, 1995, Global Volcanism Network Bulletin, v. 20, no. 9. 
Smithsonian Institution, 1999, Global Volcanism Network Bulletin, v. 24, no. 7.

Stelling, P., Beget, J., Nye, C., Gardner, J., Devine, J.D., George, R.M.M., 2002, Geology and petrology of ejecta from the 1999 eruption of Shishaldin Volcano, Alaska: Bulletin of Volcanology, v. 64, n. 8 , p. 548-561.

Thompson, G., McNutt, S.R., and Tytgat, G., 2002, Three distinct regimes of volcanic tremor associated with the eruption of Shishaldin Volcano, Alaska 1999: Bulletin of Volcanology, v. 64, n. 8 , p. 535-547.

Voight, B., Glicken, H., Janda, R.J., and Douglass, P.M., 1981, Catastrophic rockslide avalanche of May 18, in: Lipman, P.W., and Mullineaux, D.R., eds., The 1980 eruptions of Mount St.

Helens, Washington: U.S. Geological Survey Professional Paper 1250, p. 347-378.

Wood, C.A., and Kienle, J., 1990, Volcanoes of North America, Cambridge University Press, New York, $354 \mathrm{p}$. 


\section{ACKNOWLEDGMENTS}

The authors wish to thank Steve Smith, Andrea Steffke, and Courtney Kearney for help with gathering and preparing the satellite images of Kamchatka volcanoes; Susan Mayfield was the graphic artist of Figure 14. Christy Severtson was responsible for final formatting and publication layout.

Table 1. Summary of 1999 VOLCANIC ACTIVITY in Alaska, including actual eruptions, possible eruptions, and unusual increases in fumarolic activity. Locations of volcanoes shown in Figure $1 \mathrm{a}$.

\begin{tabular}{|c|c|c|}
\hline Volcano & Date of Activity & Type of Activity \\
\hline \hline Shrub Mud Volcano & spring 1997 ongoing & $\begin{array}{c}\text { Continued discharge of warm saline mud and } \\
\mathrm{CO}_{2} \text { from multiple vents; } \mathrm{CO}_{2} \text { hazard } \\
\text { recognized }\end{array}$ \\
\hline Shishaldin Volcano & February-May, 1999 & Strombolian eruption \\
\hline
\end{tabular}

Table 2. Summary of SUSPECT VOLCANIC ACTIVITY (SVA) IN 1999. SVA is defined as a report of eruption or possible eruption that is found to be normal fumarolic activity or non-volcanic phenomena, such as weather related. Location of volcanoes shown in Figure 1a.

\begin{tabular}{|c|c|c|}
\hline Volcano & Date of Activity & Type of Activity \\
\hline Wrangell Volcano & May 14,1999 & Unusual steaming and ash emission \\
\hline Iliamna Volcano & July 6,1999 & Ice and rock avalanche \\
\hline Veniaminof Volcano & July 30,1999 & $\begin{array}{c}\text { High water discharge from streams draining } \\
\text { east and northeast flanks of volcano, and } \\
\text { unusual turbidity of Chignik river into which } \\
\text { these streams flow }\end{array}$ \\
\hline Pavlof Volcano & July 13,1999 & $\begin{array}{c}\text { Summit snow melt and ash dustings; steam } \\
\text { plumes }\end{array}$ \\
\hline Vsevidof Volcano & January 28,1999 & "black smoke" reported following regional \\
earthquake
\end{tabular}


Table 3. Record of changes in the Level of Concern Color Code during the 1999 eruption of Shishaldin Volcano

\begin{tabular}{|c|c|c|}
\hline DATE & \begin{tabular}{|l} 
TIME \\
Alaska local (UTC)
\end{tabular} & COLOR CODE \\
\hline February 18, 1999 & 3:15 PM AST (0015) & YELLOW \\
\hline April 7, 1999 & 10:30 AM ADT (1830) & ORANGE \\
\hline April 12, 1999 & 9:30 PM ADT (1730) & YELLOW \\
\hline April 14, 1999 & 1:15 PM ADT (2115) & ORANGE \\
\hline April 19, 1999 & 12:15 PM ADT (2015) & RED \\
\hline April 20, 1999 & 9:45 AM ADT (1745) & ORANGE \\
\hline April 21, 1999 & 11:15 AM ADT (1915) & RED \\
\hline April 22, 1999 & 10:00 AM ADT (1800) & ORANGE \\
\hline April 22, 1999 & 9:50 PM ADT (0550) & RED \\
\hline April 23, 1999 & 7:50 AM ADT (1550) & ORANGE \\
\hline April 28, 1999 & 1:30 PM ADT (2130) & YELLOW \\
\hline May 25, 1999 & 9:30 AM ADT (1730) & ORANGE \\
\hline June 1, 1999 & 11:30 AM ADT (1930) & YELLOW \\
\hline June 18, 1999 & 12:45 PM ADT (2045) & GREEN \\
\hline
\end{tabular}


Table 4. Summary of VOLCANIC ACTIVITY on Kamchatka Peninsula, Russia, 1999. Location of volcanoes shown in Figure 14.

\begin{tabular}{|c|c|c|}
\hline Volcano & Date of Activity & Type of Activity \\
\hline \hline Sheveluch Volcano & $\begin{array}{c}\text { Intermittently } \\
\text { throughout the year }\end{array}$ & $\begin{array}{c}\text { Lava dome growth and instability continues. } \\
\text { Many short-lived, explosive episodes send ash } \\
\text { as high and 6,900 m }(\sim 23,000 \mathrm{ft}) \mathrm{ASL}\end{array}$ \\
\hline $\begin{array}{c}\text { Klyuchevskoy } \\
\text { Volcano }\end{array}$ & $\begin{array}{c}\text { Intermittently } \\
\text { throughout the year }\end{array}$ & $\begin{array}{c}\text { Continuation of 1996-98 strombolian/ } \\
\text { vulcanian eruption. Periods of elevated } \\
\text { seismicity, persistent fumarolic plume from } \\
\text { summit crater. Explosive event sent ash to } \\
7,800 \mathrm{~m}(\sim 26,000 \mathrm{ft}) \text { ASL on May 7. }\end{array}$ \\
\hline Bezymianny Volcano & $\begin{array}{c}\text { Intermittently } \\
\text { throughout the year; } \\
\text { significant plume on } \\
\text { February 25, 1999 }\end{array}$ & $\begin{array}{c}\text { Continued degassing and minor spalling of } \\
\text { new lava dome. Ash-producing explosions to } \\
7,500 \mathrm{~m}(\sim 24,600 \mathrm{ft}) \text { ASL and ash plume } \\
1,500 \mathrm{~km}(\sim 950 \text { mi) downwind on February } \\
25,1999 .\end{array}$ \\
\hline Karymsky Volcano & $\begin{array}{c}\text { Intermittently } \\
\text { throughout the year }\end{array}$ & $\begin{array}{c}\text { Low-level vulcanian/strombolian activity } \\
\text { continues intermittently through the year. New } \\
\text { lava flows. }\end{array}$ \\
\hline
\end{tabular}


Table 5. Level of Concern Color Code for volcanic activity.

\section{LEVEL OF CONCERN COLOR CODE}

To more concisely describe our level of concern about possible or ongoing eruptive activity at an Alaskan volcano, the Alaska Volcano Observatory uses the following color-coded classification system. Definitions of the colors reflect AVO's interpretations of the behavior of the volcano. Definitions are listed below followed by general description of typical activity associated with each color.

GREEN

YELLOW

ORANGE

RED
No eruption anticipated.

Volcano is in quiet, "dormant" state.

An eruption is possible in the next few weeks and may occur with little or no additional warning.

Small earthquakes detected locally and (or) increased levels of volcanic gas emissions.

Explosive eruption is possible within a few days and may occur with little or no warning. Ash plume(s) not expected to reach 25,000 feet above sea level. Increased numbers of local earthquakes. Extrusion of a lava dome or lava flows (non-explosive eruption) may be occurring.

Major explosive eruption expected within 24 hours. Large ash plume(s) expected to reach at least 25,000 feet above sea level.

Strong earthquake activity detected even at distant monitoring stations. Explosive eruption may be in progress. 


\section{FOR PHOTOGRAPHIC IMAGES OF VOLCANOES IN THIS REPORT}

Duplicate 35-mm slides and prints of some volcanoes discussed in this report are available from: The Photo Library U.S. Geological Survey MS 914 Box 25046 Federal Center Denver, CO 80225-0046 303-236-1010

Also, for digital images of Alaskan and Russian volcanoes, please see the following web sites: http://www.avo.alaska.edu http://volcanoes.usgs.gov/ http://www.volcano.si.edu/gvp/

PHOTOGRAPHS OF THE 1989-90 ERUPTIONS OF REDOUBT VOLCANO, ALASKA, USGS Open-file Report 96-689, 20 slides, 10 p. text and glossary, by A.L. Roach, C.A. Neal, and R.G. McGimsey.

PHOTOGRAPHS OF THE 1992 ERUPTIONS OF CRATER PEAK, SPURR VOLCANO, ALASKA, USGS Open-file Report 93-707, 20 slides, 8 p. text and glossary, by Christina A. Neal, Robert G. McGimsey, Michael P. Doukas, and Inyo Ellerseick, 1993. 20-slide set illustrating aspects of the 1992 eruptions. Includes captions and glossary.

VOLCANOES OF THE WRANGELL MOUNTAINS AND COOK INLET REGION, ALASKA - SELECTED PHOTOGRAPHS, U.S. Geological Survey, Digital Data Series 96-039, 1996, CDROM. Also available for download via the internet: http://wrgis.wr.usgs.gov/dds/dds-39/

VOLCANOES OF THE ALASKA PENINSULA AND ALEUTIAN ISLANDS, ALASKA SELECTED PHOTOGRAPHS, U.S. Geological Survey, Digital Data Series 96-040, 1996, CDROM. Also available for download via the internet: http://wrgis.wr.usgs.gov/dds/dds-40/

The publications listed above are available from:

U.S. Geological Survey ESIC-Open-File Report Section

Box 25286, MS 517

Denver, CO 80225-0046

303-236-7476 


\section{OTHER MULTI MEDIA PRODUCTS OF INTEREST}

"VIDEO OF THE AUGUST 18,1992, ERUPTION OF CRATER PEAK VENT ON SPURR VOLCANO, ALASKA", by Robert G. McGimsey and Joseph M. Dorava, 1994, USGS Open-File Report 94-614. This 25-minute, narrated video presents dramatic scenes of the second of three 1992 eruptions of Crater Peak, a satellite vent on Spurr Volcano, Alaska. Favorable weather conditions permitted scientists from the Alaska Volcano Observatory to photograph the eruption from a fixed-wing aircraft flying as close as $2 \mathrm{~km}$ to the vent. The video includes close-up views of the roiling, 18-kilometer-high eruption column, shockwaves emanating from the column base, ash clouds from pyroclastic flows on the southeast flank, and ash fallout downwind.

"10 YEARS OF VOLCANIC ACTIVITY IN ALASKA: 1983 TO 1992: A VIDEO", by Michael P. Doukas, Robert G. McGimsey, and Joseph M. Dorava, 1995, USGS Open-File Report 95-61. This 28-minute video presents eruption images from eight Alaskan volcanoes during the ten-year period: Veniaminof (1983-84), Augustine (1986), Redoubt (1989-90), Akutan (1991), Bogoslof (1992), Westdahl (1992), Spurr (1992), and Seguam (1992). Classic volcanic phenomena are documented, including meltwater lakes formed when lava flows advanced into an ice- filled caldera (Veniaminof), nighttime views of explosive strombolian activity (Veniaminof), pyroclastic flows descending steep flanks during plinian- and peleean- style eruptions (Augustine), hawaiian-style lava fountaining through glacial ice (Westdahl), island building in the Aleutians (Bogoslof), shock waves and close-up views of a roiling, sub-plinian eruption column rising more than 18 kilometers (Mount Spurr Volcano-Crater Peak vent).

The videotapes are available from:

U.S. Geological Survey

ESIC-Open-File Report Section

Box 25286, MS 517

Denver, CO 80225-0046

(303) 236-7476

US or Canada 1-800-684-3368

FAX (907) 273-9192

AND

Action Video

Attn: Karl Augestad

430 W. 7th Ave., Suite 100

Anchorage, AK 99501

(907) 277-8115

FAX (907) 274-8115

e-mail: actvid@alaska.net 


\section{GLOSSARY OF SELECTED TERMS}

ADT:

"Alaska Daylight Time"

AEIC:

"Alaska Earthquake Information Center"

ASL:

"above sea level"

AVO:

"Alaska Volcano Observatory"

AVHRR:

"Advanced Very High Resolution Radiometer"; AVHRR provides one form of satellite imagery

andesite:

volcanic rock composed of about 53 to 63 percent silica $\left(\mathrm{SiO}_{2}\right.$, an essential constituent of most minerals found in rocks)

ash:

fine fragments (less than 2 millimeters across) of lava or rock formed in an explosive volcanic eruption

basalt:

general term for dark-colored igneous rock, usually extrusive, containing about 45 to 52 weight percent silica $\left(\mathrm{SiO}_{2}\right.$, an essential constituent of most minerals found in rocks)

bomb:

boulder-size chunk of partly solidified lava explosively ejected from a volcano

caldera:

a large, roughly circular depression usually caused by volcanic collapse or explosion

CAVW:

Smithsonian Institute's "Catalog of Active Volcanoes of the World"

cinder cone:

small, steep-sided conical hill built mainly of cinder, spatter, and volcanic bombs

COSPEC:

"Correlation Spectrometer"; device for measuring sulfur dioxide emissions 
FAA:

"Federal Aviation Administration"

fallout:

a general term for debris which falls to the earth from an eruption cloud

fault:

a fracture or zone of fractures along which there has been displacement of the sides relative to one another

FIR:

"Flight Information Region"

FLIR

"Forward Looking Infrared Radiometer"; used to delineate objects of different temperature

fissure:

a roughly linear or sinuous crack or opening on a volcano; a type of vent which commonly produces lava fountains and flows

fumarole:

a small opening or vent from which hot gases are emitted

glaciolacustrine:

pertaining to sediments deposited in glacial lakes, and resulting landforms

GMS:

"Geostationary Meteorological Satellite"

GVN:

"Global Volcanism Network"

Holocene:

geologic epoch extending from the last present to 10,000 years ago

incandescent:

glowing red or orange due to high temperature

intracaldera:

refers to something within the caldera

IVGG:

Russian "Institute of Volcanic Geology and Geochemistry" 
JMA:

"Japanese Meteorological Agency"

KDT:

"Kamchatkan Daylight Time", which = ADT + 21 hrs.

KEMSD:

Russian "Kamchatka Experimental and Methodical Seismology Department"

KVERT:

Russian "Kamchatkan Volcano Eruption Response Team"

lava:

when molten material reaches the earth's surface, it is called lava

magma:

molten material below the surface of the earth

NOAA:

"National Oceanic and Atmospheric Administration"

NOPAC:

"North Pacific Air Corridor"

NOTAM:

"Notice to Airmen", a notice containing information [not known sufficiently in advance to publicize by other means] concerning the establishment, condition, or change in any component [facility, service, or procedure of, or hazard in the National Airspace System] the timely knowledge of which is essential to personnel concerned with flight operations

NWS:

"National Weather Service"

phreatic activity:

an explosive eruption caused by the sudden heating of ground water as it comes in contact with hot volcanic rock or magma

phreatic ash:

fine fragments of volcanic rock expelled during phreatic activity; this ash is usually derived from existing rock and not from new magma

PIREP:

"Pilot Weather Report - A report of meteorological phenomena encountered by aircraft in flight 
pixel:

contraction of "picture element". A pixel is one of the many discrete rectangular elements that form a digital image or picture on a computer monitor or stored in memory. In a satellite image, resolution describes the size of a pixel in relation to area covered on the ground. More pixels per unit area on the ground means a higher resolution.

Pleistocene:

geologic epoch extending from 2-3 million years ago to approximately 10,000 years before present

regional earthquake:

earthquake generated by fracture or slippage along a fault; not caused by volcanic activity

RFE:

"Russian Far East"

SAB:

"Synoptic Analysis Branch" of NOAA

SAR:

"Synthetic Aperture Radar"

satellite cone:

a subsidiary volcanic vent located on the flank of a larger volcano

seismic swarm:

a flurry of closely spaced earthquakes or other ground shaking activity; often precedes an eruption

shield volcano:

a broad, gently sloping volcano usually composed of fluid, lava flows of basalt composition (e.g. Mauna Loa, Hawaii)

SIGMET:

"Significant Meteorological information statement", issued by FAA

stratovolcano:

(also called a stratocone or composite cone) a steep-sided volcano, usually conical in shape, built of interbedded lava flows and fragmental deposits from explosive eruptions

strombolian:

type of volcanic eruption characterized by intermittent bursts of fluid lava, usually basalt, from a vent or crater as gas bubbles rise through a conduit and burst at the surface 
subplinian:

style of explosive eruptions characterized by vertical eruption columns and widespread dispersal of tephra

SVA:

"suspect volcanic activity"

tephra:

a general term covering all fragmental material expelled from a volcano (ash, bombs, cinders, etc.)

TFR:

“Temporary Flight Restriction”, issued by FAA

USCG:

"U.S. Coast Guard"

USGS:

"U.S. Geological Survey"

UTC:

"Coordinated Universal Time"; same as Greenwich Mean Time (GMT)

VAAC:

"Volcanic Ash Advisory Center"

vent:

an opening in the earth's surface through which magma erupts or volcanic gasses are emitted

volcano-tectonic earthquakes:

earthquakes generated within a volcano from brittle rock failure resulting from strain induced by volcanic processes

UAFGI:

"University of Alaska Fairbanks Geophysical Institute" 